\title{
Energy Impacts of Heat Island Reduction Strategies in the Greater Toronto Area, Canada
}

\author{
Prepared for: \\ Toronto Atmospheric Fund \\ Steven Konopacki and Hashem Akbari \\ Heat Island Group \\ Lawrence Berkeley National Laboratory \\ Berkeley, California 94720
}

November 2001

This work was supported by the Toronto Atmospheric Fund (TAF) under Contract No. BG01-150(00) and the Assistant Secretary for Energy Efficiency and Renewable Energy, Building Technologies, of the U.S. Department of Energy (DOE) under contract No. DE-AC03-76SF00098. 


\section{Acknowledgements}

This work was supported by the Toronto Atmospheric Fund (TAF) under Contract No. BG01150(00) and the Assistant Secretary for Energy Efficiency and Renewable Energy, Building Technologies, of the U.S. Department of Energy (DOE) under contract No. DE-AC0376SF00098. The authors acknowledge the support and guidance of Eva Ligeti (TAF) throughout the completion of the project. 


\title{
Energy Impacts of Heat Island Reduction Strategies in Toronto, Canada
}

\author{
Steven Konopacki and Hashem Akbari, Heat Island Group \\ Lawrence Berkeley National Laboratory, Berkeley, California 94720
}

\begin{abstract}
In 2000, the Toronto Atmospheric Fund (TAF) embarked on an initiative to quantify the potential benefits of Heat Island Reduction (HIR) strategies (shade trees, reflective roofs and pavements) in reducing cooling energy use in buildings, lowering the ambient air temperature and improve air quality. This report summarizes the efforts of Lawrence Berkeley National Laboratory (LBNL) to assess the impacts of HIR measures on building cooling- and heating-energy use.

We discuss our efforts to calculate annual energy savings and peak-power avoidance of HIR strategies in the building sector of the Greater Toronto Area. The analysis is focused on three major building types that offer most saving potentials: residence, office and retail store. Using an hourly building energy simulation model, we quantify the energy saving potentials of (1) using cool roofs on individual buildings [direct effect], (2) planting deciduous shade trees near south and west walls of building [direct effect], (3) planting coniferous wind-shielding vegetation near building [direct effect], (4) ambient cooling by a large-scale program of urban reforestation with reflective building roofs and pavements [indirect effect], (5) and the combined direct and indirect effects.
\end{abstract}

Results show potential annual energy savings of over $\$ 11 \mathrm{M}$ (with uniform residential and commercial electricity and gas prices of $\$ 0.084 / \mathrm{kWh}$ and $\$ 5.54 / \mathrm{GJ}$ ) could be realized by ratepayers from the combined direct and indirect effects of HIR strategies. Of that total, about $88 \%$ was from the direct impact roughly divided equally among reflective roofs, shade trees and windshielding, and the remainder (12\%) from the indirect impact of the cooler ambient air temperature. The residential sector accounts for over half $(59 \%)$ of the total, offices $13 \%$ and retail stores $28 \%$. Savings from cool roofs were about $20 \%$, shade trees $30 \%$, wind shielding of tree $37 \%$, and indirect effect $12 \%$. These results are highly sensitive to the price of gas. Assuming a residential gas price of $\$ 10.84 / \mathrm{GJ}$ (gas price during December 2001), the net annual savings are reduced to about $\$ 10 \mathrm{M}$; about $78 \%$ resulted from wind-shielding, $16 \%$ from shading by trees, and $5 \%$ from cool roofs.

Potential annual electricity savings were estimated at about $150 \mathrm{GWh}$ or over $\$ 12 \mathrm{M}$, of that about $75 \%$ accrued from roofs and shade trees and only $2 \%$ from wind shielding. The indirect effect was $23 \%$. Potential peak-power avoidance was estimated at $250 \mathrm{MW}$ with about $74 \%$ attributed to the direct impacts (roofs about $24 \%$, shade trees $51 \%$ and wind-shielding a small negative $\%$ ) and the remainder $(26 \%)$ to the indirect impact. The greatest part of avoided peak power (about $83 \%$ ) was because of the effects of the residences and the rest shared by offices (7\%) and retail stores $(9 \%)$. 


\title{
Energy Impacts of Heat Island Reduction Strategies in Toronto, Canada
}

\author{
Steven Konopacki and Hashem Akbari, Heat Island Group \\ Lawrence Berkeley National Laboratory, Berkeley, California 94720
}

\section{Executive Summary}

In 2000, the Toronto Atmospheric Fund (TAF) embarked on an initiative to quantify the potential benefits of Heat Island Reduction (HIR) strategies (i.e. shade trees, reflective roofs, reflective pavements and urban reforestation) to reduce cooling energy use in buildings, lower the ambient air temperature and improve air quality. This report summarizes the efforts of Lawrence Berkeley National Laboratory (LBNL) to assess the impacts of HIR measures on building coolingand heating-energy use. A companion report will address the air quality aspect (Taha et al., 2002).

\section{Background}

During the summer, solar-reflective roofs (also known as "high-albedo" or "cool" roofs) reflect most of the incoming sunlight and reduce the amount of heat conduction into a building. Similarly, strategically placed trees, shading windows and walls of a building, reduce the amount of direct heat gain. The reduction in summer heat gains because of cool roofs and shade trees reduces the air-conditioning load of a building, improves thermal comfort, saves peak-demand electricity, and saves money. During the winter, cool roofs and shade trees may add to the heating load of a building. However, the heating-energy penalties are fairly small, since most of the heating is required during the evening hours (when there is no sunshine), winter days are shorter and cloudier than summer days, and buildings may have snow on the roofs. Furthermore, trees can actually save heating-energy bills by shielding a building from cold winter wind.

Cool surfaces (roofs and pavements) together with urban vegetation (shade trees, park trees, lawn, etc.) can potentially cool the city by a few degrees. Lowered urban air temperatures can further reduce cooling-energy demand. More importantly, cooler ambient conditions can also slow the rate of $\operatorname{smog}\left(\mathrm{O}_{3}\right)$ formation and have a significant impact on ambient air quality. Observational data from Los Angeles, California indicate that the peak daily concentration of ozone increases by about $4-5 \%$ per ${ }^{\circ} \mathrm{C}\left(2-3 \%\right.$ per $\left.{ }^{\circ} \mathrm{F}\right)$ in the temperature range of $21-38^{\circ} \mathrm{C}\left(70-100^{\circ} \mathrm{F}\right)$ (Akbari et al., 2001).

It is noted that summertime temperatures in Toronto have been steadily increasing with the expansion of the city. In addition, most new buildings are equipped with air-conditioners; as a result, the local utility company has changed from a winter peaking to a summer peaking utility. The impact of higher temperatures in the summer can potentially make air-quality problems more severe.

\section{Project Objective}

The objective of this project was to assess the impacts of Heat Island Reduction (HIR) measures on building cooling- and heating-energy use and ambient air quality in Toronto. This report summarizes our efforts to calculate annual energy savings and peak-power avoidance of HIR strategies in the Greater Toronto Area (GTA). In this analysis, we focused on the effect of vari-

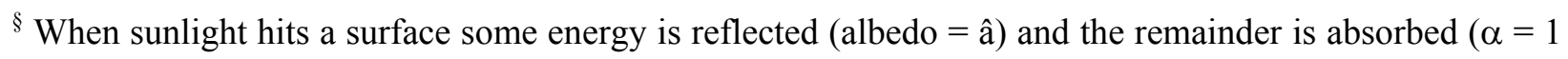
-â). High-â surfaces become cooler than low-â surfaces and consequently lower the cooling load of a building.
} 
ous HIR strategies on three major building types that offer most savings potential: residence, office and retail store. The HIR strategies include:

A. Use of solar-reflective roofing material on building [direct effect].

B. Placement of deciduous shade trees near south and west walls of building [direct effect].

C. Placement of coniferous wind-shielding vegetation near building [direct effect].

D. Urban reforestation with reflective building surfaces and pavements [indirect effect].

E. Combination of strategies A through D [direct and indirect effects].

\section{Methodology}

The focus of the project was to obtain an estimate of savings potentials of HIR measures. HIR measures have a significant effect on energy use of small residential and commercial buildings; HIR measures do not affect the energy use of large multistory commercial buildings typically located in the downtown area. Hence, we focused our efforts mostly on single-family residential and low-rise commercial buildings (office and retail store). In previous studies, these building types accounted for over $90 \%$ of potential savings of HIR measures.

A five-step methodology was developed to access the potential impact of HIR measures on building and metropolitan-wide energy use in Toronto.

1. Define prototypical-building characteristics in detail for pre-1980 and 1980+ construction.

2. Simulate annual energy use and peak demand using the DOE-2.1E model.

3. Determine direct and indirect energy and demand savings from each HIR strategy.

4. Identify the total roof area of air-conditioned buildings (residences, offices, and retail stores) in the GTA

5. Calculate the metropolitan-wide impact of HIR strategies.

We modeled a total of 20 prototypes including ten residential [pre-1980 (old) singles family houses, 1980+ (new) single-family houses, R-2000 single-family houses, pre-1980 (old) rowhouses, 1980+ (new) row-houses; all modeled with both gas and electric heating systems], four office buildings [pre-1980 (old) offices, 1980+ (new) offices; both modeled with gas and electric heating systems], and four retail buildings [pre-1980 (old) retail buildings, 1980+ (new) retail buildings; both modeled with gas and electric heating systems].

\section{Building Energy Simulations}

The simulations predicted annual total energy savings of about 3-5\% from combined direct and indirect effects for old $17-22 \$ / 100 \mathrm{~m}^{2}$ and new $9 \$ / 100 \mathrm{~m}^{2}$ gas-heated single-family and rowhouse residences. This number increased to $10 \%$ for offices $\left[40 \$ / 100 \mathrm{~m}^{2}\right.$ for new and $100 \$ / 100 \mathrm{~m}^{2}$ for old] and $12 \%$ for retail stores $\left[40 \$ / 100 \mathrm{~m}^{2}\right.$ for new and $100 \$ / 100 \mathrm{~m}^{2}$ for old]. Electric-heated units did not fair so well, where savings of $0-2 \%$ were observed for residences and $5-9 \%$ for offices and retail stores because the electric heating penalty is more expensive than that of gas.

As expected, an increase in the heating energy use was found for all building types and in each HIR mitigation strategy with the exception of wind shielding, since this measure reduces the heating requirements of a building. The annual gas deficit for combined direct and indirect effects was $2-6 \$ / 100 \mathrm{~m}^{2}$ for residences, $11-12 \$ / 100 \mathrm{~m}^{2}$ for offices and only $0-3 \$ / 100 \mathrm{~m}^{2}$ for retails.

Simulated peak power reduction was significant for all building types and strategies, except for wind shielding. Combined direct and indirect peak-demand reduction in cooling electricity was $21-23 \%$ in residences and $13-16 \%$ in offices and retails. This translates into 0.57- 
$0.61 \mathrm{~kW} / 100 \mathrm{~m}^{2}$ for pre-1980 residences, $0.33-0.40 \mathrm{~kW} / 100 \mathrm{~m}^{2}$ for $1980+$ residences, $0.60-$ $1.13 \mathrm{~kW} / 100 \mathrm{~m}^{2}$ for old and new offices, and $0.36-0.71 \mathrm{~kW} / 100 \mathrm{~m}^{2}$ for old and new retails.

\section{Potential Metropolitan-Wide Benefits}

The Greater Toronto Area (GTA) has a population of over 4.2 million with nearly 1.5 million households and is situated inland, on the northwestern edge of Lake Ontario. The Toronto summer is hot and brief with a cooling season from May through September. The winter is cold from November through March [Average summer peak temperature is $34^{\circ} \mathrm{C}$ and average winter minimum temperature is $-24^{\circ} \mathrm{C}$. Typically, there are about 320 cooling degree-days and 4200 heating degree-days, base $18.3^{\circ} \mathrm{C}$ ]. Most residential buildings are two-story and commercial buildings are low-rises. The saturation of air-conditioning is high in both residential and commercial buildings. The total roof area of residential, office and retail buildings with air-conditioning was 40, 1.9 and $3.4 \mathrm{Mm}^{2}$, respectively, and about $75 \%$ built prior to 1980 .

The potential metropolitan-wide benefits assume full implementation of HIR measures and were calculated in the form of annual energy savings [M\$], annual electricity savings in giga watthour $[\mathrm{GWh}]$ and $[\mathrm{M} \$]$, annual natural gas deficit in peca Joule $\left[\mathrm{PJ}=10^{15} \mathrm{~J}\right]$ and $[\mathrm{M} \$]$, and avoided peak power mega watt [MW].

Results show potential annual energy savings of over $\$ 11 \mathrm{M}$ (with uniform residential and commercial electricity and gas prices of $\$ 0.084 / \mathrm{kWh}$ and $\$ 5.54 / \mathrm{GJ}$ ) could be realized by ratepayers from the combined direct and indirect effects of HIR strategies. Of that total, about $88 \%$ was from the direct impact roughly divided equally among reflective roofs, shade trees and windshielding, and the remainder (12\%) from the indirect impact of the cooler ambient air temperature. The residential sector accounts for over half (59\%) of the total, offices $13 \%$ and retail stores $28 \%$. Savings from cool roofs were about $20 \%$, shade trees $30 \%$, wind shielding of tree $37 \%$, and indirect effect $12 \%$. These results are highly sensitive to the price of gas. Assuming a residential gas price of $\$ 10.84 / \mathrm{GJ}$ (gas price during December 2001), the net annual savings are reduced to \$10M; about 78\% resulted from wind-shielding, 16\% from shading by trees, and 5\% from cool roofs. (These results are fairly intuitive, as the higher prices of gas make winter heating penalties more expensive.)

Potential annual electricity savings were estimated at about $150 \mathrm{GWh}$ or over $\$ 12 \mathrm{M}$, of that about $75 \%$ accrued from roofs and shade trees and only $2 \%$ from wind shielding. The indirect effect from a modified urban fabric was $23 \%$. The savings distributed among buildings is similar to those cited above.

The potential annual natural gas deficit was estimated to be over $0.23 \mathrm{PJ}$ or just under $\$ 1-2 \mathrm{M}$, with actual savings of over \$4-8M from wind shielding and a combined penalty of under \$3$7 \mathrm{M}$. Residences accounted for about $94 \%$ of the gas deficit since these commercial buildings require very little heating.

Potential peak-power avoidance was estimated at about $250 \mathrm{MW}$ with about $74 \%$ attributed to the direct impacts (roofs about 24\%, shade trees 51\% and wind-shielding a small negative \%) and the remainder $(26 \%)$ to the indirect impact. The greatest part of avoided peak power (about $83 \%$ ) was because of the effects of the residences and the rest shared by offices (7\%) and retail stores $(9 \%)$.

\section{Discussion}

The results of this study are preliminary by nature. The objective of the project was to perform a preliminary analysis and to develop a database of potential energy- and peak-demand savings from the implementation of HIR measures (i.e., cool roofs, shade trees, and cool pavements). To perform such a study, we focused on three building types (residential, office, and retail) that offer 
the highest potential savings for the GTA. The primary reason we focused on these three building types was that these buildings constitute over $90 \%$ of the floor area of all building stock in the GTA. HIR technologies are also very effective on other building types such as hospitals, schools, restaurants, grocery stores, etc. However, the potential savings from these other buildings only contribute a few percent additional savings for the entire GTA

The analysis included both the direct and indirect effects of three heat-island reduction measures on heating- and cooling-energy use of several prototypical residential and commercial buildings. The prototypical savings were then extrapolated to obtain savings potentials for the Greater Toronto Area. In reviewing the results of this analysis, the following should be considered:

1. Reflective roofs and shade trees reduce summer cooling-energy use and also potentially increase winter heating-energy use. The net savings (\$ savings in cooling energy use $-\$$ penalties in heating-energy use) is highly sensitive to prices of cooling- and heating-energy fuels. In the residential building prototypes cooled and heated with electricity, we found that most of the cooling-energy savings are written off by the penalties in heating-energy use). Since reflective roofs and shade trees affect the energy performance of a building typically for 2030 years, a better understanding of long-term trends in energy prices would lead to better estimates of savings potentials.

2. Trees affect the energy use of a building by shading and wind shielding. Our capabilities to simulate the shading effects of trees are typically more refined than simulating the windshielding effects. Future studies to investigate further the wind-shielding effects of trees on heating-energy use would improve the current estimates.

3. DOE-2 currently underestimates the cooling-energy saving potentials of reflective roofs by as much as a factor of two. Hence, the saving potentials shown for reflective roofs should be considered as conservative. Furthermore, during the winter, some of the roofs are covered with snow. Hence the heating penalties of reflective roofs are potentially overestimated. A few monitoring and demonstration projects at the GTA would lead to a better understanding of the actual saving potentials in the region.

4. Although the simulations were performed for office, retail store, and residential prototypes, the results are normalized by roof area for each prototype. These results can be used to estimate savings potentials in other building types. For instance, one can comfortably estimate savings for a hospital based on the results obtained for office buildings.

5. The total roof area for commercial buildings in the GTA was estimated using an approach based on the population and the residential roof area. A more direct estimate of the actual roof area for commercial buildings can improve the accuracy of the estimates.

6. The indirect saving potentials were only a small fraction of total potential savings. Hence, for energy saving potentials consideration, reflective roofs and shade trees that save energy both directly and indirectly should be given a higher priority than reflective pavements that only save energy indirectly. 



\section{Table of Contents}

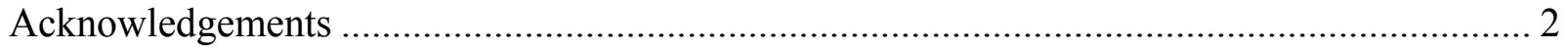

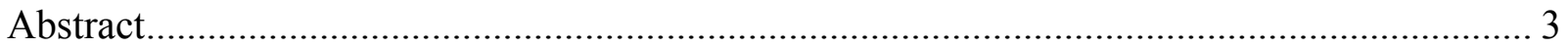

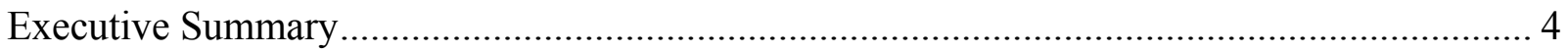

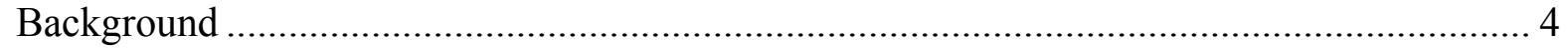



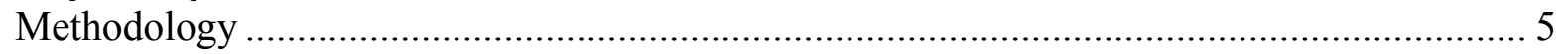

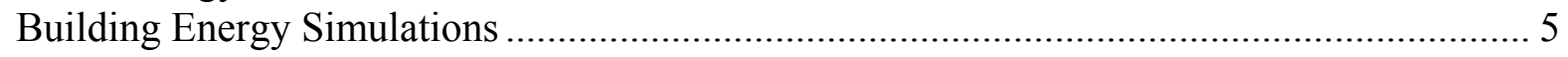

Potential Metropolitan-Wide Benefits .............................................................................. 6

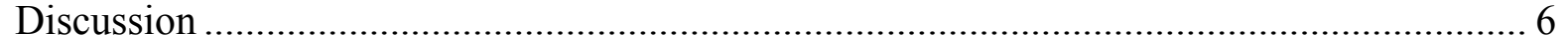

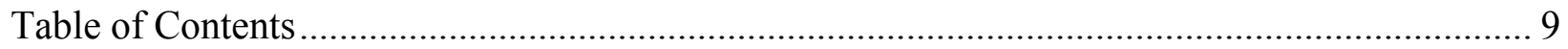

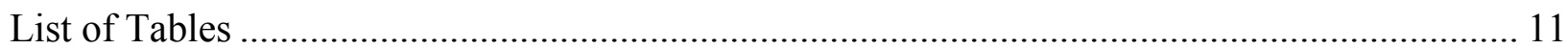

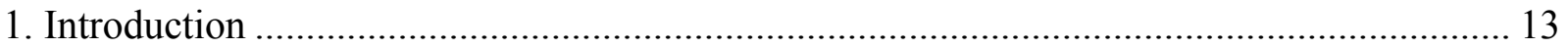

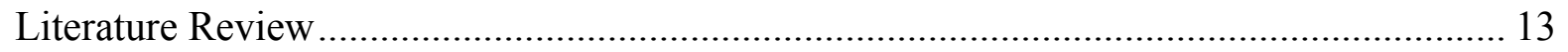

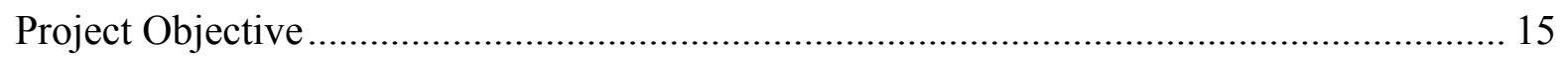

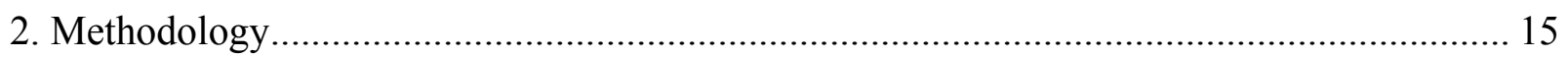

1. Define prototypical building characteristics in detail for pre-1980

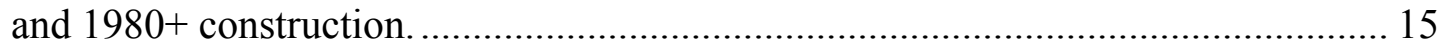

2. Simulate annual energy use and peak demand using the DOE-2.1E model. .................... 16

3. Determine direct and indirect energy and demand savings from each HIR strategy......... 16

4. Identify total roof area of air-conditioned buildings in the GTA...................................... 16

5. Calculate the metropolitan-wide impact of HIR strategies............................................. 16

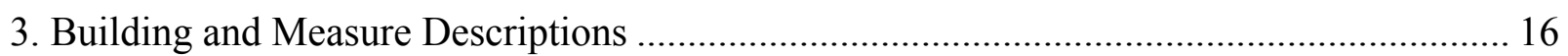

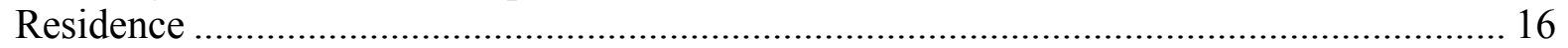

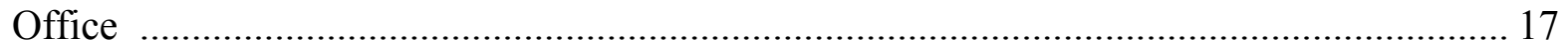

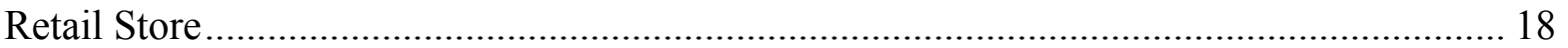

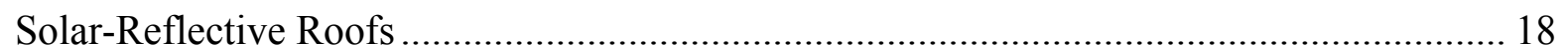

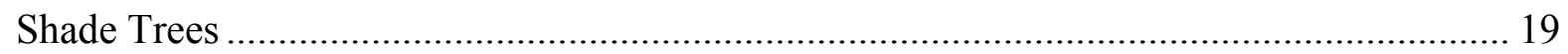

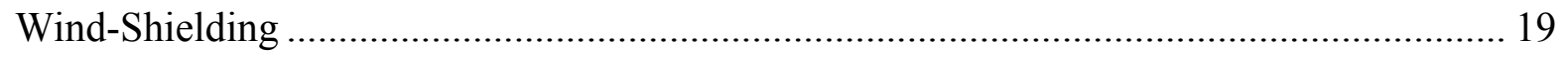

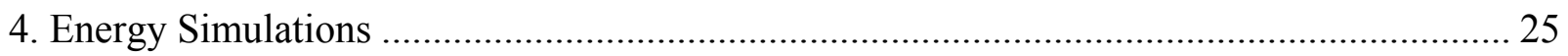

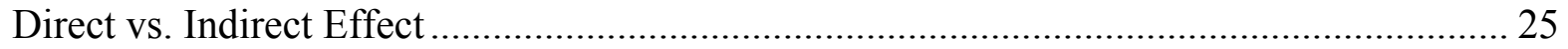

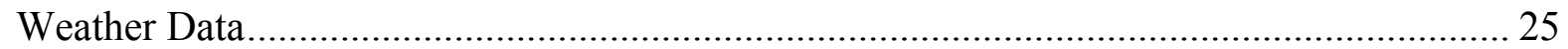

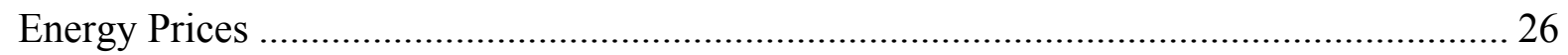

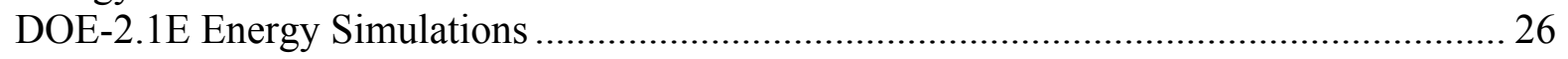

5. Air-Conditioned Roof Area Calculations .......................................................................... 31

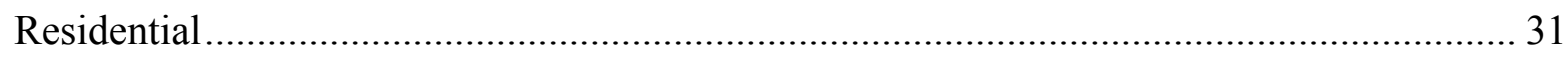

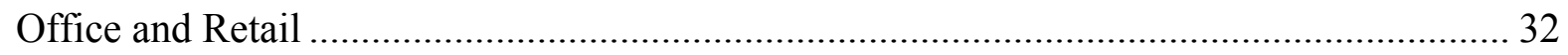

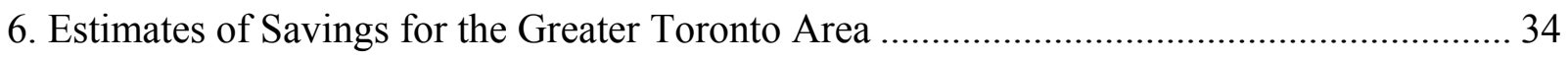

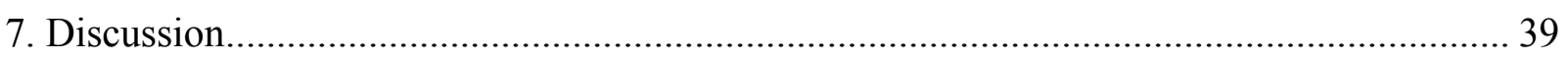



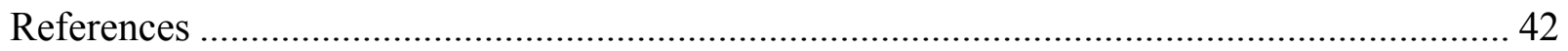

Appendix A. Building Information Data Sources .................................................................. 45 



\section{List of Tables}

Table 3.1(a). Prototypical building description for the Greater Toronto Area:

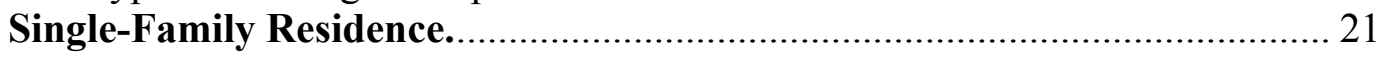

Table 3.1(b). Prototypical building description for the Greater Toronto Area:

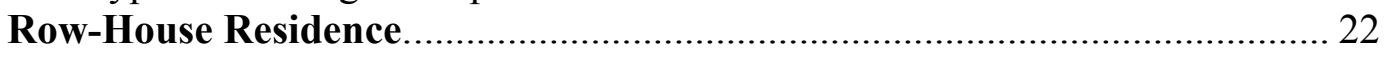

Table 3.2. Prototypical Building Description for the Greater Toronto Area: Office.............. 23

Table 3.3. Prototypical Building Description for the Greater Toronto Area:

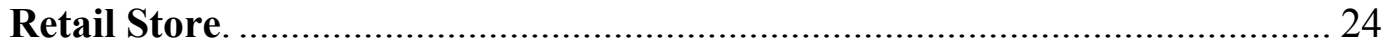

Table 4.1. Standard and modified Toronto WYEC2 weather data with cooling and heating degree-days and maximum air temperature tallied monthly

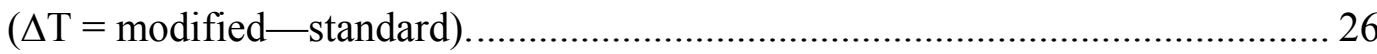

Table 4.2(a). Toronto simulated cooling and heating annual base expenditures and savings [electricity: $\mathrm{kWh} / 100 \mathrm{~m}^{2}$, gas: $\mathrm{GJ} / 100 \mathrm{~m}^{2}$ ], and peak-power demand and savings $\left[\mathrm{kW} / 100 \mathrm{~m}^{2}\right]$ from heat-island reduction strategies

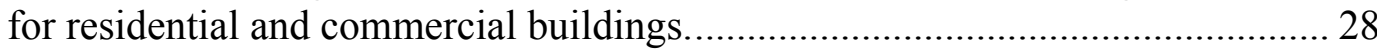

Table 4.2(b). Toronto simulated cooling and heating annual base expenditures and savings $\left[\$ / 100 \mathrm{~m}^{2}\right]$ from heat-island reduction strategies for residential and commercial buildings (residential gas price of $\$ 5.54 / \mathrm{GJ}$ ).

Table 4.2(c). Toronto simulated cooling and heating annual base expenditures and savings $\left[\$ / 100 \mathrm{~m}^{2}\right]$ from heat-island reduction strategies for residential and commercial buildings (residential gas price of $\$ 10.84 / \mathrm{GJ}$ ). 30

Table 5.1. Calculation of air-conditioned roof area $\left[\mathrm{Mm}^{2}\right]$ for residential buildings in the Greater Toronto Area. 33

Table 5.2. Calculation of air-conditioned roof area $\left[\mathrm{Mm}^{2}\right]$ for office and retail buildings in the Greater Toronto Area.

Table 6.1. The Greater Toronto Area estimates of cooling and heating annual energy savings and avoided peak power from heat-island reduction strategies for residential and commercial buildings. Direct savings are from the use of solar-reflective roofs, strategic placement of deciduous shade trees and wind-shielding vegetation. Indirect savings include the effect of reduced ambient air temperature from a modified urban fabric.

Table 6.2a. The Greater Toronto Area estimates of cooling and heating annual base energy expenditures and savings $[\mathrm{M} \$]$ from heat-island reduction strategies for residential and commercial buildings (residential gas price of $\$ 5.54 / \mathrm{GJ})$...... 37

Table 6.2b. The Greater Toronto Area estimates of cooling and heating annual base energy expenditures and savings [M\$] from heat-island reduction strategies for residential and commercial buildings (residential gas price of $\$ 10.84 / \mathrm{GJ})$.... 38

Table A.1. Housing characteristics in the Greater Toronto Area. ......................................... 46

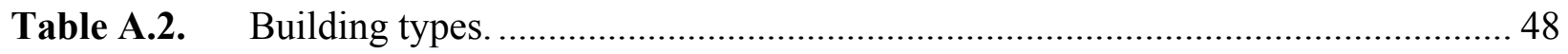

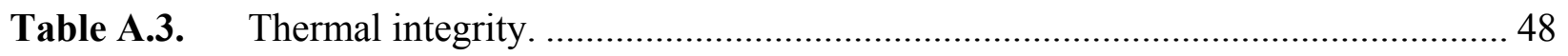

Table A.4. Internal loads, equipment, and thermostat settings...........................................49 



\section{Introduction}

During the summer, solar-reflective roofs (also known as "high-albedo" " or "cool" roofs) reflect most of the incoming sunlight and reduce the amount of heat conduction into a building. Similarly, strategically placed trees, shading windows and walls of a building reduce the amount of direct heat gain. The reduction in summer heat gains because of cool roofs and shade trees reduces the air-conditioning load of a building, improves thermal comfort, saves peak-demand electricity, and saves money. During the winter, cool roofs and shade trees may add to the heating load of a building. However, the heating-energy penalties are fairly small, since most of the heating is required during the evening hours (when there is no sunshine), winter days are shorter and cloudier than summer days, and buildings may have snow on the roofs. Furthermore, trees can actually save heating-energy bills by shielding a building from cold winter wind (Akbari et al., 1990).

Cool surfaces (roofs and pavements) together with urban vegetation (shade trees, park trees, lawn, etc.) can potentially cool the city by a few degrees. Lowered urban air temperatures can further reduce cooling-energy demand. More importantly, cooler ambient conditions can slow the rate of smog $\left(\mathrm{O}_{3}\right)$ formation and have a significant impact on ambient air quality. Observational data from Los Angeles, California indicate that the peak daily concentration of ozone increases by about $4-5 \%$ per ${ }^{\circ} \mathrm{C}\left(2-3 \%\right.$ per $\left.{ }^{\circ} \mathrm{F}\right)$ in the temperature range of $21-38^{\circ} \mathrm{C}\left(70-100^{\circ} \mathrm{F}\right)$ (Akbari et al., 2001).

It is noted that summertime temperatures in Toronto have been steadily increasing with the expansion of the city (Jessup, 2000). In addition, most new buildings are equipped with airconditioners. As a result, the local utility company has changed from a winter-peaking to a summer-peaking utility. The impact of higher temperatures in the summer can potentially make airquality problems more severe.

\section{Literature Review}

Energy savings from the use of solar-reflective roofs and shade trees have been predicted through computer simulations and verified with measured data in both residential and commercial buildings. The majority of these studies have focused on reflective roofs.

In a pilot study, Konopacki et al. (1997) used computer simulations to estimate the direct energy impact from solar-reflective roofs in eleven U.S. Metropolitan Statistical Areas (MSAs). The study reported metropolitan-wide estimates of total residential and commercial annual energy and electricity savings, annual gas deficit (winter heating penalties), avoided peak power and annual carbon reduction. The results showed that three major building types accounted for over $90 \%$ of the annual electricity and monetary savings: old residences $(55 \%)$, new residences $(15 \%)$, and old/new office buildings and retail stores together $(25 \%)$. Furthermore, these three building types accounted for $93 \%$ of the total air-conditioned roof area. The metropolitan-wide savings were a function of energy savings in the air-conditioned buildings, stock of residential and commercial buildings, percentage of buildings that were air-conditioned, and the number of floors per building (roof area). Populous cities with an older low-rise building stock, in hot and sunny climates, and with a high level of a/c saturation provided the highest savings potential for HIR strategies. Metropolitan-wide savings were as much as \$37M for Phoenix and \$35M in Los Angeles and as low as $\$ 3 \mathrm{M}$ in the heating-dominated climate of Philadelphia.

\footnotetext{
${ }^{\S}$ When sunlight hits a surface some energy is reflected (albedo $\left.=\hat{a}\right)$ and the remainder is absorbed $(\alpha=1$ -â). High-â surfaces become cooler than low-â surfaces and consequently lower the cooling load of a building.
} 
In a recent study using a methodology similar to the pilot project, Konopacki and Akbari (2000) have estimated the direct and indirect energy impacts of all HIR measures in three U.S. metropolitan areas: Baton Rouge, Sacramento and Salt Lake City. The analysis indicated that for the three respective cities, potential annual energy savings (cooling energy savings minus heating energy penalties) of $\$ 15 \mathrm{M}, \$ 26 \mathrm{M}$ and $\$ 3.6 \mathrm{M}$, peak-power avoidance of $130 \mathrm{MW}, 490 \mathrm{MW}$ and $85 \mathrm{MW}$, and annual carbon reduction of $40 \mathrm{kt}, 92 \mathrm{kt}$ and $20 \mathrm{kt}$ could be realized from full implementation of HIR measures.

Other studies using computer simulations to estimate the impact of solar-reflective roofs include Konopacki and Akbari (1998a), Akbari et al. (1998), Parker et al. (1998a) and Gartland et al. (1996). Additionally, Taha et al. (1996) have modeled the impact of shade trees. Finally, Akbari and Taha (1992) have estimated the impact of reflective surfaces and trees in four Canadian cities (including Toronto). The building prototypes included a detached one-story and a detached two-story, and a two-story row-house. The simulations indicated that by increasing the vegetative cover by $30 \%$ and increasing the albedo of houses by 0.2 (from moderate-dark to mediumlight color), the heating-energy use in Toronto can be reduced by $10 \%$ in urban houses and $20 \%$ in rural houses (mostly because of wind-shielding effect of trees). The cooling-energy use can be reduced by about $30 \%-40 \%$.

In addition to computer simulations, several field studies have documented measured airconditioning summertime energy savings that result from the use of solar-reflective roof systems. These studies were conducted in warm-weather climates, mostly in Florida and California, on residential and commercial buildings. In a recent study, Konopacki and Akbari (2001) have estimated daily energy savings of $39 \mathrm{Wh} / \mathrm{m}^{2}\left(3.6 \mathrm{Wh} / \mathrm{ft}^{2}\right)(11 \%)$ and peak-power reduction of $3.8 \mathrm{~W} / \mathrm{m}^{2}\left(0.35 \mathrm{~W} / \mathrm{ft}^{2}\right)(14 \%)$ in a large retail store in Austin from the application of a reflective membrane. Akbari and Rainer (2000) measured daily a/c energy savings of $33 \mathrm{Wh} / \mathrm{m}^{2}\left(3.1 \mathrm{Wh} / \mathrm{ft}^{2}\right)$ $(1 \%)$ in two Nevada telecommunication regeneration buildings. Konopacki et al. (1998) have demonstrated the impact of reflective roofs in three California commercial buildings, two medical offices and one retail store, summertime daily air-conditioning savings of $68 \mathrm{Wh} / \mathrm{m}^{2}(6.3$ $\left.\mathrm{Wh} / \mathrm{ft}^{2}\right), 39 \mathrm{Wh} / \mathrm{m}^{2}\left(3.6 \mathrm{Wh} / \mathrm{ft}^{2}\right)$ and $4.3 \mathrm{Wh} / \mathrm{m}^{2}\left(0.4 \mathrm{Wh} / \mathrm{ft}^{2}\right)(18 \%, 13 \%$ and $2 \%)$ and reduced demand of $3.3 \mathrm{~W} / \mathrm{m}^{2}\left(0.31 \mathrm{~W} / \mathrm{ft}^{2}\right), 2.4 \mathrm{~W} / \mathrm{m}^{2}\left(0.22 \mathrm{~W} / \mathrm{ft}^{2}\right)$ and $1.6 \mathrm{~W} / \mathrm{m}^{2}\left(0.15 \mathrm{~W} / \mathrm{ft}^{2}\right)(12 \%, 8 \%$ and 9\%). Akbari et al. (1997a) have shown from an increase in roof reflectance in one monitored Sacramento house daily summertime cooling-energy savings of $14 \mathrm{Wh} / \mathrm{m}^{2}\left(1.3 \mathrm{Wh} / \mathrm{ft}^{2}\right)(63 \%)$ and peak-power reduction of $3.6 \mathrm{~W} / \mathrm{m}^{2}\left(0.33 \mathrm{~W} / \mathrm{ft}^{2}\right)(25 \%)$, and in a Sacramento school bungalow, cooling-energy savings of $47 \mathrm{Wh} / \mathrm{m}^{2}\left(4.4 \mathrm{Wh} / \mathrm{ft}^{2}\right)(46 \%)$ and peak-power reduction of $6.8 \mathrm{~W} / \mathrm{m}^{2}$ $\left(0.63 \mathrm{~W} / \mathrm{ft}^{2}\right)(20 \%)$. In an office, museum and hospice with reflective roofs in Sacramento, Hildebrandt et al. (1998) measured daily a/c savings of $10 \mathrm{Wh} / \mathrm{m}^{2}\left(0.9 \mathrm{Wh} / \mathrm{ft}^{2}\right), 20 \mathrm{Wh} / \mathrm{m}^{2}\left(1.9 \mathrm{Wh} / \mathrm{ft}^{2}\right)$ and $11 \mathrm{Wh} / \mathrm{m}^{2}\left(1.0 \mathrm{Wh} / \mathrm{ft}^{2}\right)(17 \%, 26 \%$ and 39\%). Parker et al. (1998a) have monitored the performance of reflective roofs in eleven Florida residences with daily savings ranging from 5$137 \mathrm{Wh} / \mathrm{m}^{2}\left(0.5-12.7 \mathrm{Wh} / \mathrm{ft}^{2}\right)(2-43 \%)$ and peak-demand reduction of $1.5-7.7 \mathrm{~W} / \mathrm{m}^{2}(0.14-$ $\left.0.72 \mathrm{~W} / \mathrm{ft}^{2}\right)(12-28 \%)$. Parker et al. (1999) measured daily energy savings of $17 \%$ from a reflective roof in a high-efficiency home in Florida. Parker et al. (1997) have also monitored seven retail stores within a strip mall in Florida before and after applying a reflective roof coating and measured a $7.5 \mathrm{Wh} / \mathrm{m}^{2}\left(0.7 \mathrm{Wh} / \mathrm{ft}^{2}\right)(25 \%)$ drop in daily summertime cooling-energy use and a $0.65 \mathrm{~W} / \mathrm{m}^{2}\left(0.06 \mathrm{~W} / \mathrm{ft}^{2}\right)(29 \%)$ decrease in demand. Parker et al. (1998b) measured daily energy savings of $44 \mathrm{Wh} / \mathrm{m}^{2}\left(4.1 \mathrm{Wh} / \mathrm{ft}^{2}\right)(25 \%)$ and peak-power reduction of $6.0 \mathrm{~W} / \mathrm{m}^{2}\left(0.56 \mathrm{~W} / \mathrm{ft}^{2}\right)(30 \%)$ from a reflective roof on a school building in Florida. Akridge (1998) reported daily savings of $75 \mathrm{Wh} / \mathrm{m}^{2}\left(7.0 \mathrm{Wh} / \mathrm{ft}^{2}\right)(28 \%)$ for an education building in Georgia, the unpainted galvanized roof of which was coated with white acrylic. An office building in southern Mississippi was shown to save $22 \%$ after the application of a reflective roof coating (Boutwell and Salinas 1986). 
In two monitored houses in Sacramento, Akbari et al. (1997b) have demonstrated that seasonal cooling-energy savings of $30 \%$ and peak-power savings of $35 \%$ can be realized with the placement of shade trees near the buildings.

\section{Project Objective}

The objective of this project was to assess the impacts of Heat Island Reduction (HIR) measures on building cooling- and heating-energy use and ambient air quality in the Greater Toronto Area (GTA). This report summarizes our efforts to calculate the annual energy savings and peakpower avoidance resulting from the implementation of HIR strategies in the GTA ${ }^{\S}$. In this analysis, we focused on the effect of various HIR strategies on three major building types that offer most savings potential: residence, office and retail store. The HIR strategies include:

A. Use of solar-reflective roofing material on buildings [direct effect].

B. Placement of deciduous shade trees near south and west walls of buildings [direct effect].

C. Placement of coniferous wind-shielding vegetation near buildings [direct effect].

D. Urban reforestation with reflective building surfaces and pavements [indirect effect].

E. Combination of strategies A through D [direct and indirect effects].

\section{Methodology}

The focus of the project was to obtain an estimate of the savings potentials of HIR measures. HIR measures have a significant effect on the energy use of small residential and commercial buildings; HIR measures do not affect the energy use of large multistory commercial buildings typically located in the downtown area. Hence, we focused our efforts mostly on single-family residential and low-rise commercial building (office and retail store). In previous studies, these building types accounted for over $90 \%$ of the potential savings resulting from the implementation of HIR measures.

We modeled a total of 20 prototypes including ten residential [pre-1980 (old) single-family houses, 1980+ (new) single-family houses, R-2000 single-family houses, pre-1980 (old) rowhouses, 1980+ (new) row-houses; all modeled with both gas and electric heating systems], four office buildings [pre-1980 (old) offices, 1980+ (new) offices; both modeled with gas and electric heating systems], and four retail buildings [pre-1989 (old) retail buildings, 1980+ (new) retail buildings; both modeled with gas and electric heating systems].

A five-step methodology was developed to access the potential impact of HIR measures on building and metropolitan-wide energy use in the GTA.

\section{Define prototypical building characteristics in detail for pre-1980 and 1980+ construction.}

Prototypical building data were identified and used to define construction, internal load, and cooling and heating equipment characteristics for residential, office and retail buildings. The prototypes were developed for both pre-1980 and 1980+ construction vintages (and R-2000 for the residence) and with both gas and electricity heating fuels. The use of existing and reflective roofs, the placement of deciduous shade trees about the south and west sides of the building and northern wind-shielding were considered. These data then defined the characteristics of the Building Description Language used by the DOE-2.1E energy simulation computer program. Building data for residences were obtained from two primary sources. (Sources of data for building characteristics information are summarized in Appendix A.) The first is an analysis of a

\footnotetext{
$\S$ A companion report will address the air quality aspect of HIR in the GTA (Taha et al., 2002).
} 
Natural Resources Canada survey of 1361 houses in the GTA (NRCAN, 2001a), and the second is a study by Akbari et al. (1992) that estimated the impact of trees and reflective roofs on residential cooling- and heating-energy use in four Canadian cities.

\section{Simulate annual energy use and peak demand using the DOE-2.1E model.}

The DOE-2 building-energy model was used to simulate the direct impact of reflective roofs, shade trees and wind-shielding on cooling- and heating-energy use for several prototypical buildings in the GTA. The DOE-2 model simulates energy use of a building for 8,760 hours of a year, using typical hourly weather data. The MM5 mesoscale meteorological model was used to simulate the impact of urban surface modifications on the cooling of the regional ambient air. Following that step, the Toronto Weather Year for Energy Consumption (WYEC2) data was modified to account for this ambient cooling. The rerun of the DOE-2 simulations with the modified weather data quantified the indirect impact of HIR measures on building-energy use. Local electricity and natural gas rates were applied to the simulation results to obtain total annual energy use in dollars.

\section{Determine direct and indirect energy and demand savings from each HIR strategy.}

Simulated annual cooling- and heating-energy savings and avoided peak power were calculated by comparing the base case energy use and demand to those of the HIR strategies.

\section{Identify total roof area of air-conditioned buildings in the GTA.}

Total air-conditioned roof area for the entire GTA was estimated for residential, office (including high-rises) and retail buildings. Residential roof area was calculated with data obtained from Statistics Canada (STATCAN, 1996), Natural Resources Canada (NRCAN, 2001a), ICLEI (1997) and the Survey of Household Energy Use (NRCAN, 1995). Commercial building roof area was calculated from a methodology described in Konopacki et al. (1997).

\section{Calculate the metropolitan-wide impact of HIR strategies.}

Savings from building-energy simulations were combined with the total air-conditioned roof area for each prototype and HIR strategy to determine metropolitan-wide impact.

\section{Building and Measure Descriptions}

Three major building prototypes were selected for investigation in this project: [1] residence [2] office [3] retail store. In a detailed study to quantify the impact of reflective roofs in eleven Metropolitan Statistical Areas (MSAs), Konopacki et al. (1997) showed that these three building types accounted for $93 \%$ of the residential and commercial air-conditioned roof area. The buildings were characterized for old (pre-1980: built prior to 1980) and new (1980+: built in 1980 or later) construction vintages; an R-2000 residence was also modeled. Two heating fuels were available for each prototype, natural gas and electricity. The prototype characteristics were written into Building Description Language (BDL) for DOE-2 modeling.

\section{Residence}

The residence was modeled in two configurations: [1] single-family detached and [2] singlefamily row-house. The single-family structure was also modeled for R-2000 design. According to Natural Resources Canada (2001a), about $60 \%$ of existing single-family detached (SFD) houses are two-story and $23 \%$ single story; the average floor area is about $280 \mathrm{~m}^{2}\left(3000 \mathrm{ft}^{2}\right)$. The newer (post 1980) SFD houses are about 90\% two-story and 7\% three-story (less than 3\% are one-story); the average floor area is about $350 \mathrm{~m}^{2}\left(3800 \mathrm{ft}^{2}\right)$. For all existing row-houses, about

$64 \%$ are two-story and $27 \%$ three-story; the average floor area is $170 \mathrm{~m}^{2}\left(1800 \mathrm{ft}^{2}\right)$. The newer 
$(1980+)$ row-houses were about $62 \%$ two-story and $37 \%$ three-story with an average floor area of about $150 \mathrm{~m}^{2}\left(1600 \mathrm{ft}^{2}\right)$.

Changing the reflectance of the roof, mostly affects the heat transfer through the roof structure. We present the simulated data by normalizing the savings per $100 \mathrm{~m}^{2}$ of roof area. Then in calculating the savings for the GTA, we accounted for the number of stories of the building stock.

The roof was constructed with asphalt shingles on a $20^{\circ}$ sloped plywood deck, over a naturally ventilated and unconditioned attic, above a studded ceiling frame with fiberglass insulation (varying by vintage), and with a sheet of drywall beneath. The fractional-leakage-area of the attic and living quarters were dependent on vintage. Variable air infiltration was modeled by the Sherman-Grimsrud algorithm (Sherman et al., 1986). The existing solar reflectance of the roof was 0.2 , typical for asphalt shingles, and the albedo of the reflective roof was taken to be 0.5 , the value for prototype white shingles and a typical value for aged white roof coatings. The thermal emittance of both roofs was 0.9 .

The single-family detached residence was cooled and heated by a central air-conditioning system (with ducts located in the conditioned space), a constant volume fan, and without an economizer. The multi-family row-house was served by a ductless window or room a/c unit with heating provided by a gas wall furnace or electric resistance. Cooling through natural ventilation was available by window operation. System size and efficiency were selected for each vintage. A Seasonal Energy Efficiency Ratio (SEER) of 12 or greater is the standard for an Energy Star ${ }^{\circledR}$ qualifying central air-conditioner, and a Heating Season Performance Factor (HSPF) of 7 for an air-source heat pump (U.S.DOE 2001). The minimum SEER allowed today is 10.

Modified part-load-ratio curves for a typical air-conditioner, heat pump and gas furnace were used in place of the standard DOE-2 curves, since they have been shown to model low-energy use more accurately (Henderson, 1998). Duct loads were simulated with a validated residential duct function (Parker et al., 1998a) implemented into DOE-2 to better estimate the thermal interactions between the ducts and space. The function was designed for the residential central system type (RESYS) in DOE-2 and for a single air-conditioned living space with an attic and basement. Since this function greatly improves cooling and heating energy use estimates and the top story of a building receives the primary benefits of a reflective roof, the single-story residential structure was modeled.

Building data for residences are shown in Tables 3.1 (a,b) and were obtained from several sources: an analysis of a Natural Resources Canada (NRCAN, 2001a) survey of 1361 houses in the GTA, and a study by Akbari et al. (1992), which estimated the impact of trees and reflective roofs on residential cooling and heating energy use in four Canadian cities. Additionally, characteristics for 1980+ construction homes were identified from DOE national appliance energy standards (NAECA, 1987), California's Title 24, the Model Energy Code, and Energy Star ${ }^{\circledR}$ (U.S.DOE, 2001).

\section{Office}

The office was modeled as a non-directional building with four perimeter zones and a core zone, also in two construction vintages, those built prior to 1980, those built in 1980 and after. The floor plan was a $21.3 \mathrm{~m}$ by $21.3 \mathrm{~m}\left(70^{\prime}\right.$ by $\left.70^{\prime}\right)$ layout with a total air-conditioned floor area of $455 \mathrm{~m}^{2}\left(4900 \mathrm{ft}^{2}\right)$. The perimeter zone depth was $4.6 \mathrm{~m}\left(15^{\prime}\right)$. The building operated from 6am to $7 \mathrm{pm}$ on weekdays only.

The roof was constructed with built-up materials on a flat plywood deck, over an unventilated and unconditioned plenum, above a studded ceiling frame with fiberglass insulation (varying by vintage), and with a sheet of drywall beneath. The existing solar reflectance of the roof was 0.2 , 
typical for gray or tan built-up, and the albedo of the reflective roof was taken to be 0.6 , typical for aged white roof coatings. The thermal emittance of both roofs was 0.9 .

The building was cooled and heated by five rooftop, constant volume, packaged-single-zone systems, each one servicing a single zone. The systems were sized based on peak-cooling and heating loads as determined by DOE-2, which allowed for peak loads to be met and for maximum savings to be calculated. Duct loads were simulated by specifying air leakage and temperature drop. An economizer was also implemented. A Seasonal Energy Efficiency Ratio (SEER) of 12 or greater is the standard for an Energy Star ${ }^{\circledR}$ qualifying central air-conditioner, and a Heating Season Performance Factor (HSPF) of 7 for an air-source heat pump (U.S.DOE, 2001). The minimum currently allowed SEER is 10 .

Specific building characteristics data for the commercial sector in the GTA were not available. Office characteristics were taken from previous research focusing on the impact of reflective roofs in eleven U.S. metropolitan areas (Konopacki et al., 1997) and Energy Star ${ }^{\circledR}$ (U.S.DOE, 2001). These office building characteristics are displayed in Table 3.2.

\section{Retail Store}

The retail store was modeled as a non-directional building with a single zone, also in two construction vintages, those built prior to 1980 (pre-1980), those built in 1980 and after (1980+). The floor plan was a 90' by 90' layout with $8100 \mathrm{ft}^{2}$ of total air-conditioned floor area. The building operated from $8 \mathrm{am}$ to $9 \mathrm{pm}$ on weekdays and from $10 \mathrm{am}$ to $5 \mathrm{pm}$ on weekends and holidays.

The roof was constructed with built-up materials on a flat plywood deck, over an unventilated and unconditioned plenum, above a studded ceiling frame with fiberglass insulation, and with a sheet of drywall beneath. The existing solar reflectance of the roof was 0.2 , typical for gray or tan built-up, and the albedo of the reflective roof was taken to be 0.6 , typical for aged white roof coatings. The thermal emittance of both roofs was 0.9 .

The building was cooled and heated by a single rooftop, constant volume packaged-single-zone system. The system was sized based on peak cooling and heating loads as determined by DOE2, which allowed for peak loads to be met and for maximum savings to be calculated. Duct loads were simulated by specifying air leakage and temperature drop. An economizer was also implemented. A Seasonal Energy Efficiency Ratio (SEER) of 12 or greater is the standard for an Energy Star ${ }^{\circledR}$ qualifying central air-conditioner, and a Heating Season Performance Factor (HSPF) of 7 for an air-source heat pump (U.S.DOE, 2001). The minimum SEER allowed today is 10 .

Specific building characteristic data for the commercial sector in the GTA were not available. Retail store characteristics were taken from previous research focusing on the impact of reflective roofs in 11 U.S. metropolitan areas (Konopacki et al., 1997) and Energy Star ${ }^{\circledR}$ (U.S.DOE, 2001). These retail store building characteristics are displayed in Table 3.3.

\section{Solar-Reflective Roofs}

A solar-reflective roof is typically light in color and absorbs less sunlight than a conventional dark-colored roof. Less absorbed sunlight means a lower surface temperature, which directly reduces heat gain through the roof and air-conditioning demand. Typical values of albedo for low- and high-albedo roofs were selected to cover the wide range of commercially available roofing materials (shingles, tiles, membranes and coatings) and the effects of weathering and aging. These were obtained primarily from the Cool Roofing Materials Database (CRMD, 2001) developed at LBNL, containing measured values of roof absorptance across the solar spectrum. 
For the sloped-roof residential sector, commercially available high-reflective materials are scarce. White asphalt shingles are available, but have a relatively low albedo of $0.2-0.25$. White coatings can be applied to shingles or tiles to obtain an aged albedo of about 0.5. Some highreflective white shingles are being developed, but are only in the prototype stage. Also, some reflective tiles are available. Conversely, high-reflective materials for the low-slope commercial sector are on the market. White acrylic, elastomeric and cementatious coatings can now be applied to built-up roofs to achieve an aged solar-reflectance of 0.6 and likewise for white thermoplastic membranes.

The values of roof albedo were chosen to be 0.2 and 0.5 for residential roofs and 0.2 and 0.6 for commercial roofs, which represent low and high albedo materials. The long-wave thermal emittance of these materials was a uniform 0.9. In DOE-2 the ABSORPTANCE keyword for roof construction was 0.8 for the base case and was changed to 0.5 and 0.4 for residential and commercial reflective roofs, respectively.

Bretz and Akbari (1997) have reported that the albedo of white-coated roof surfaces can degrade up to $20 \%$ over a period of several years as a result of weathering and accumulation of dirt and debris (microbial growth can contribute to degradation in humid climates), and by washing the roof, the albedo can be restored to $90-100 \%$ of the initial value. Note, rainfall can cleanse a roof and in most cases have the same effect as a thorough washing.

A "generic white" asphalt shingle has a laboratory tested initial albedo of 0.25 (CRMD, 2001). A "generic gray" asphalt shingle has a laboratory tested initial albedo of 0.22 , and the albedo of a green or brown shingle is about 0.12-0.15 (CRMD, 2001). The roofs-built-up asphalt capsheet with light-gray granules - of three commercial buildings in California were coated with a whiteelastomeric material, where the measured pre-coated albedo ranged from 0.16 to 0.24 , the initial post-coated albedo was 0.6 , the unwashed albedo ranged from 0.47 to 0.56 , and the washed albedo was 0.59 (Konopacki and Akbari, 1998b).

Shade Trees

Shade trees block incoming sunlight to the windows and walls of a building and effectively lower cooling demand. Deciduous shade trees shed their leaves in the winter to allow sunlight to warm the building. Mature deciduous shade trees were modeled in DOE-2 with the BUILDING$S H A D E$ keyword as a box-shaped building shade with seasonal transmittance ${ }^{\xi}$. The summertime transmittance was 0.1 for 1 April through 31 October and wintertime was 0.9 for the remainder of the year. The geometry of the modeled tree consisted of a square cross-sectional area of $21 \mathrm{~m}^{2}$ $\left(225 \mathrm{ft}^{2}\right), 4.6 \mathrm{~m}$ by $4.6 \mathrm{~m}$ (15' by $\left.15^{\prime}\right)$, a depth of $3 \mathrm{~m}$ (10'), and a canopy height of $4.6 \mathrm{~m}\left(15^{\prime}\right)$. They were placed outside the south and west walls near the windows (with $0.6 \mathrm{~m}$ of clearance from the building) in order to maximize the impact on the building-cooling load. The fullygrown trees shade a portion of the roof during low sun hours, but do not cover any of it during high sun hours. The number of shade trees modeled were 4,8 and 10 for the residence, office and retail store, respectively.

\section{Wind-Shielding}

Trees and shrubbery shield the walls and portions of the roof from wind directly reducing wind speed, thus reducing outside air film conductance and wind-speed dependent infiltration. The tree-planting strategy consists in placing coniferous vegetation on the north side of a building to shield cold northerly winds, and to locate deciduous foliage on the south and west sides. In a heating-dominant climate such as Toronto, the net effect yielded savings in annual energy ex-

\footnotetext{
$\xi$ The fraction of light that passes through the tree is the transmittance.
} 
penditures. The shielding impact on reducing seasonal heating expenditures was greater than the slight increase in cooling costs.

The wind-shielding effect on cooling and heating use was modeled within DOE-2 by altering the three following BDL Building-Location keywords: [1] SHIELDING-COEFFICIENT [2] TERRAIN-PAR1 [3] TERRAIN-PAR2 (Winklemann et al., 1993). The Shielding-Coefficient value is used in calculating the Sherman-Grimsrud infiltration. The coefficient modifies the wind speed term in the model to account for changes in the wind pressure caused by local obstructions. A value of 0.19 representing typical suburban shielding was used for base simulations; this was altered to 0.17 . The wind speed was also modified for terrain and space height effects at the building site using the keywords Terrain-Par1 and Terrain-Par2. Values of 0.85 and 0.20 representing rural area with low buildings and trees were altered to 0.81 and 0.21 . 
Table 3.1(a). Prototypical building description for the Greater Toronto Area: Single-Family Residence.

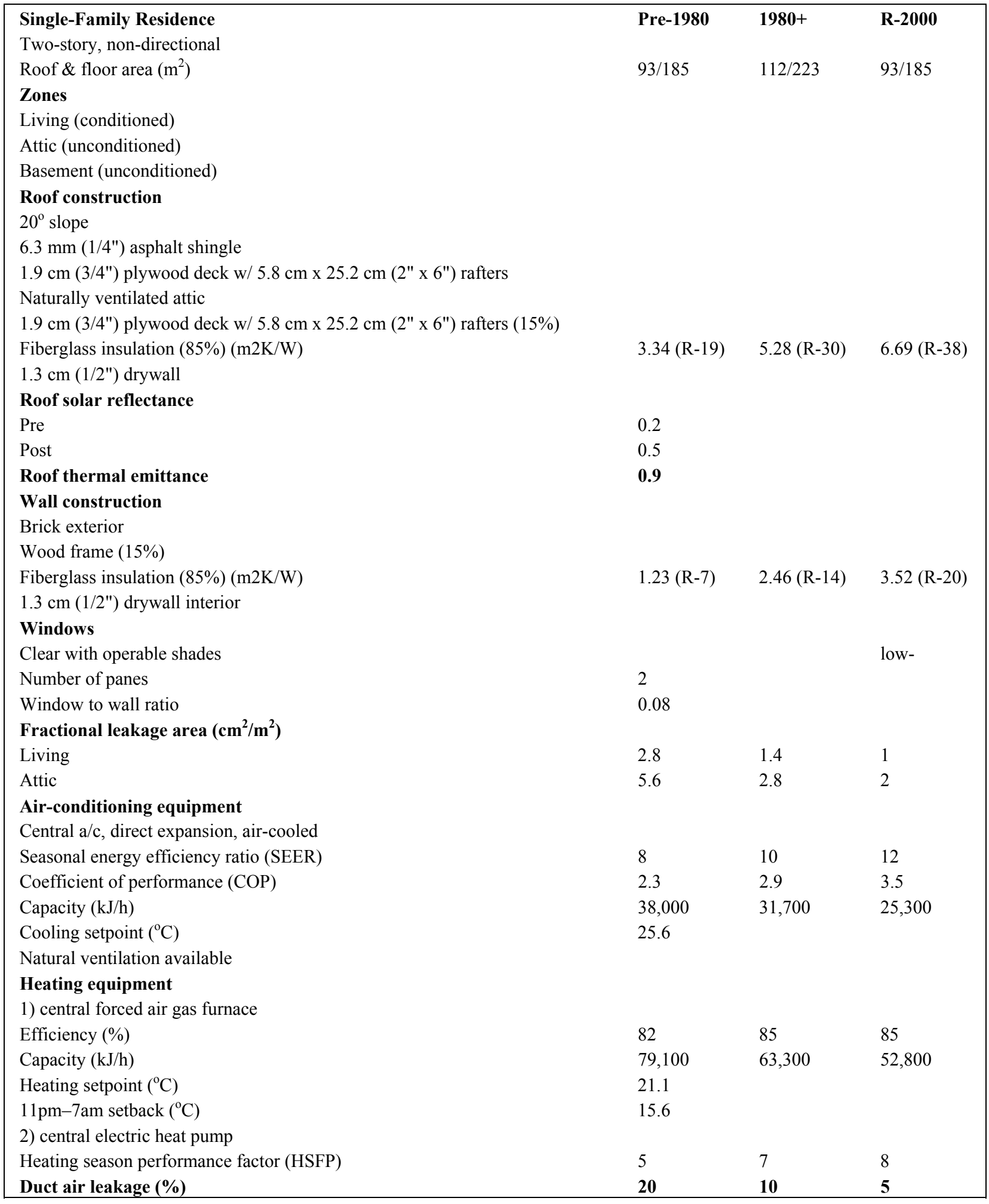


Table 3.1(b). Prototypical building description for the Greater Toronto Area: Row-House

Residence.

\begin{tabular}{|c|c|c|c|}
\hline Row-House Residence & Pre-1980 & $1980+$ & $\mathbf{R 2 0 0 0}$ \\
\hline Two-story, non-directional & & & \\
\hline Roof \& floor area $\left(\mathrm{m}^{2}\right)$ & $56 / 112$ & $46 / 93$ & $56 / 112$ \\
\hline \multicolumn{4}{|l|}{ Zones } \\
\hline \multicolumn{4}{|l|}{ Living (conditioned) } \\
\hline \multicolumn{4}{|l|}{ Attic (unconditioned) } \\
\hline \multicolumn{4}{|l|}{ Basement (unconditioned) } \\
\hline \multicolumn{4}{|l|}{ Roof construction } \\
\hline \multicolumn{4}{|l|}{ 20o slope } \\
\hline \multicolumn{4}{|l|}{$6.3 \mathrm{~mm}(1 / 4 ")$ asphalt shingle } \\
\hline \multicolumn{4}{|l|}{$1.9 \mathrm{~cm}(3 / 4 ")$ plywood deck w/ $5.8 \mathrm{~cm}$ x $15.2 \mathrm{~cm}(2 "$ x 6") rafters } \\
\hline \multicolumn{4}{|l|}{ Naturally ventilated attic } \\
\hline \multicolumn{4}{|l|}{$1.9 \mathrm{~cm}(3 / 4 ")$ plywood deck w/ $5.8 \mathrm{~cm}$ x $15.2 \mathrm{~cm}(2 " \mathrm{x} 6 ")$ rafters (15\%) } \\
\hline Fiberglass insulation $(85 \%)(\mathrm{m} 2 \mathrm{~K} / \mathrm{W})$ & $2.29(\mathrm{R}-13)$ & $5.28(\mathrm{R}-30)$ & $6.69(\mathrm{R}-38)$ \\
\hline \multicolumn{4}{|l|}{$1.3 \mathrm{~cm}(1 / 2 ")$ drywall } \\
\hline \multicolumn{4}{|l|}{ Roof solar reflectance } \\
\hline Pre & 0.2 & & \\
\hline Post & 0.5 & & \\
\hline Roof thermal emittance & 0.9 & & \\
\hline \multicolumn{4}{|l|}{ Wall construction } \\
\hline \multicolumn{4}{|l|}{ Brick exterior } \\
\hline \multicolumn{4}{|l|}{ wood frame $(15 \%)$} \\
\hline Fiberglass insulation $(85 \%)(\mathrm{m} 2 \mathrm{~K} / \mathrm{W})$ & $1.06(\mathrm{R}-6)$ & $2.64(\mathrm{R}-15)$ & $3.52(\mathrm{R}-20)$ \\
\hline \multicolumn{4}{|l|}{$1.3 \mathrm{~cm}(1 / 2 ")$ drywall interior } \\
\hline \multicolumn{4}{|l|}{ Windows } \\
\hline \multicolumn{4}{|l|}{ Clear with operable shades } \\
\hline Number of panes & 2 & & \\
\hline window to wall ratio & 0.11 & & \\
\hline \multicolumn{4}{|l|}{ Fractional leakage area $\left(\mathrm{cm}^{2} / \mathrm{m}^{2}\right)$} \\
\hline Living & 2.8 & 0.7 & 0.7 \\
\hline Attic & 6.2 & 2.1 & 1.4 \\
\hline \multicolumn{4}{|l|}{ Air-conditioning equipment } \\
\hline \multicolumn{4}{|l|}{ window or room a/c, direct expansion } \\
\hline Seasonal energy efficiency ratio (SEER) & 6 & 10 & 12 \\
\hline Coefficient of performance (COP) & 2.3 & 2.9 & 3.5 \\
\hline Capacity $(\mathrm{kJ} / \mathrm{h})$ & 38,000 & 31,700 & 25,300 \\
\hline Cooling setpoint $\left({ }^{\circ} \mathrm{C}\right)$ & 25.6 & & \\
\hline \multicolumn{4}{|l|}{ Natural ventilation available } \\
\hline \multicolumn{4}{|l|}{ Heating equipment } \\
\hline \multicolumn{4}{|l|}{ 1) wall mounted gas furnace } \\
\hline Efficiency $(\%)$ & 81 & 92 & 92 \\
\hline Capacity $(\mathrm{kJ} / \mathrm{h})$ & 42,200 & 38,000 & 31,700 \\
\hline Heating setpoint $\left({ }^{\circ} \mathrm{C}\right)$ & 21.1 & & \\
\hline $11 \mathrm{pm}-7$ am setback $\left({ }^{\circ} \mathrm{C}\right)$ & 15.6 & & \\
\hline 2) electric resistance & & & \\
\hline Duct air leakage (\%) & - & - & \\
\hline
\end{tabular}


Table 3.2. Prototypical Building Description for the Greater Toronto Area: Office.

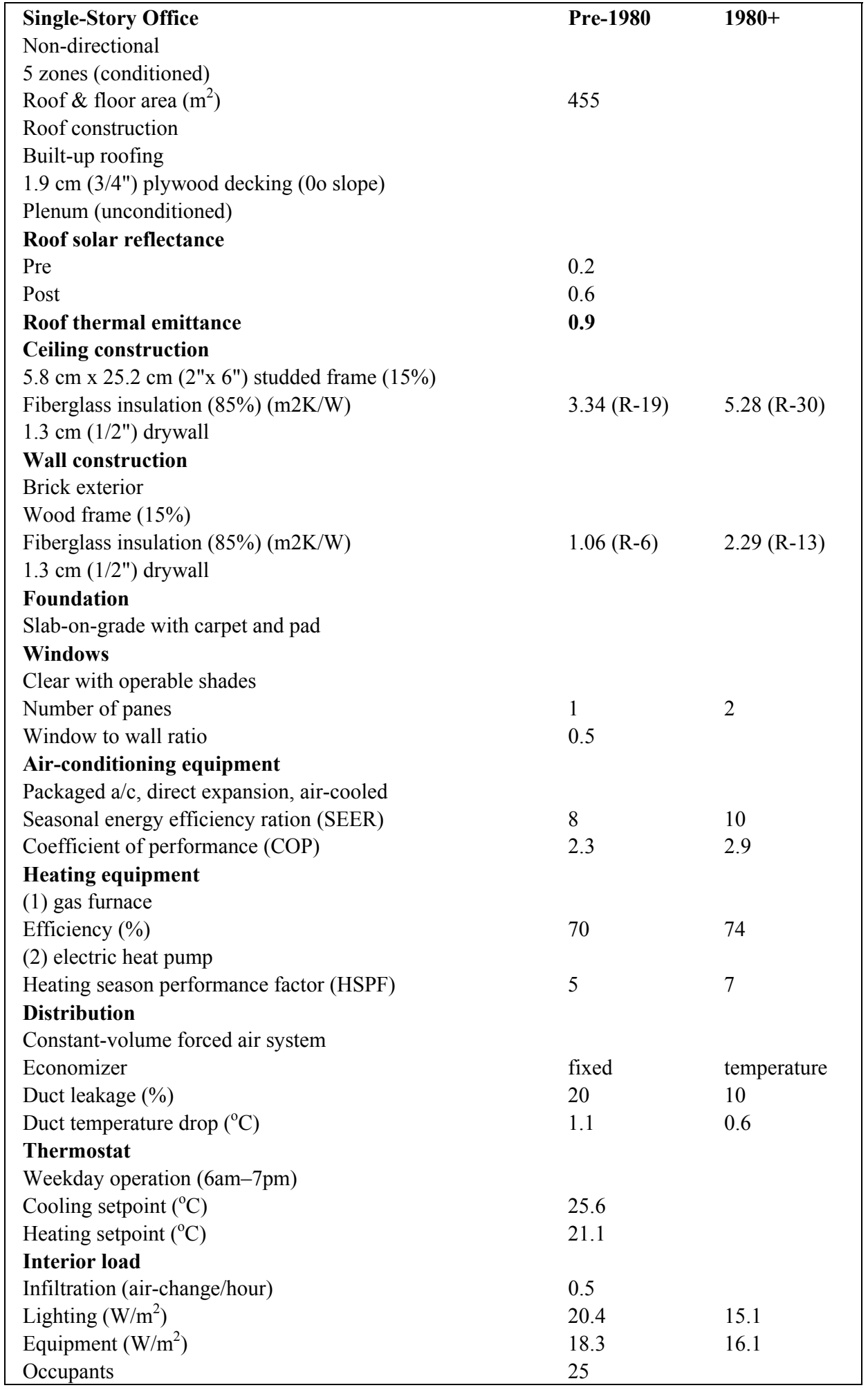


Table 3.3. Prototypical Building Description for the Greater Toronto Area: Retail Store.

\begin{tabular}{|c|c|c|}
\hline Single-Story Office & Pre-1980 & $1980+$ \\
\hline \multicolumn{3}{|l|}{ Non-directional } \\
\hline \multicolumn{3}{|l|}{5 zones (conditioned) } \\
\hline Roof \& floor area $\left(\mathrm{m}^{2}\right)$ & 750 & \\
\hline \multicolumn{3}{|l|}{ Roof construction } \\
\hline \multicolumn{3}{|l|}{ Built-up roofing } \\
\hline \multicolumn{3}{|l|}{$1.9 \mathrm{~cm}(3 / 4 ")$ plywood decking (0o slope) } \\
\hline \multicolumn{3}{|l|}{ Plenum (unconditioned) } \\
\hline \multicolumn{3}{|l|}{ Roof solar reflectance } \\
\hline Pre & 0.2 & \\
\hline Post & 0.6 & \\
\hline Roof thermal emittance & 0.9 & \\
\hline \multicolumn{3}{|l|}{ Ceiling construction } \\
\hline \multicolumn{3}{|l|}{$5.8 \mathrm{~cm}$ x $25.2 \mathrm{~cm}(2 " \mathrm{x} 6 ")$ studded frame (15\%) } \\
\hline Fiberglass insulation $(85 \%)(\mathrm{m} 2 \mathrm{~K} / \mathrm{W})$ & $3.34(\mathrm{R}-19)$ & $5.28(\mathrm{R}-30)$ \\
\hline \multicolumn{3}{|l|}{$1.3 \mathrm{~cm}(1 / 2 ")$ drywall } \\
\hline \multicolumn{3}{|l|}{ Wall construction } \\
\hline \multicolumn{3}{|l|}{ Brick exterior } \\
\hline \multicolumn{3}{|l|}{ Wood frame $(15 \%)$} \\
\hline Fiberglass insulation $(85 \%)(\mathrm{m} 2 \mathrm{~K} / \mathrm{W})$ & $0.70(\mathrm{R}-4)$ & $2.29(\mathrm{R}-13)$ \\
\hline \multicolumn{3}{|l|}{$1.3 \mathrm{~cm}\left(1 / 2^{\prime \prime}\right)$ drywall } \\
\hline \multicolumn{3}{|l|}{ Foundation } \\
\hline \multicolumn{3}{|l|}{ Slab-on-grade with carpet and pad } \\
\hline \multicolumn{3}{|l|}{ Windows } \\
\hline \multicolumn{3}{|l|}{ Clear with operable shades } \\
\hline Number of panes & 1 & 2 \\
\hline Window to wall ratio & 0.17 & \\
\hline \multicolumn{3}{|l|}{ Air-conditioning equipment } \\
\hline \multicolumn{3}{|l|}{ Packaged a/c, direct expansion, air-cooled } \\
\hline Seasonal energy efficiency ration (SEER) & 8 & 10 \\
\hline Coefficient of performance (COP) & 2.3 & 2.9 \\
\hline \multicolumn{3}{|l|}{ Heating equipment } \\
\hline Efficiency $(\%)$ & 70 & 74 \\
\hline \multicolumn{3}{|l|}{ (2) electric heat pump } \\
\hline Heating season performance factor (HSPF) & 5 & 7 \\
\hline Distribution & & \\
\hline Constant-volume forced air system & & \\
\hline Economizer & fixed & temperature \\
\hline Duct leakage (\%) & 20 & 10 \\
\hline Duct temperature $\operatorname{drop}\left({ }^{\circ} \mathrm{C}\right)$ & 3 & 1 \\
\hline Thermostat & & \\
\hline Weekday operation (6am-7pm) & & \\
\hline Weekend operation (10am-5pm) & & \\
\hline Cooling setpoint $\left({ }^{\circ} \mathrm{C}\right)$ & 25.6 & \\
\hline Heating setpoint $\left({ }^{\circ} \mathrm{C}\right)$ & 21.1 & \\
\hline Interior load & & \\
\hline Infiltration (air-change/hour) & 0.5 & \\
\hline Lighting $\left(\mathrm{W} / \mathrm{m}^{2}\right)$ & 25.8 & 18.3 \\
\hline Equipment $\left(\mathrm{W} / \mathrm{m}^{2}\right)$ & 7.5 & 6.5 \\
\hline Occupants & 16 & \\
\hline
\end{tabular}




\section{Energy Simulations}

Annual cooling- and heating-energy use and peak-power demand were simulated on an hourly time-step with the DOE-2.1E building-energy simulation program (BESG, 1990) using Toronto climate data for residential, office and retail store building prototypes, and for each Heat Island Reduction (HIR) strategy. Local residential and commercial electricity and natural gas rates were applied to the simulation results to obtain total annual energy use in dollars.

Direct vs. Indirect Effect

Strategies to cool cities and mitigate urban heat islands include planting shade trees around buildings, planting other urban vegetation in parks and along roadways, and using solarreflective roofs and pavements. Trees shade buildings, and reflective roofs reflect solar energy from buildings, directly reducing demand for air-conditioning $(\mathrm{a} / \mathrm{c})$. Vegetation can reduce wind velocity near a building and consequently reduce heat loss; thus, wind-shielding directly increases a/c use and decreases heating demand. Urban vegetation and reflective surfaces (roofs and pavements) alter the surface-energy balance of an area through the evapotranspiration provided by vegetation and by the reflection of incident solar energy, lowering the ambient temperature and hence indirectly reducing a/c use (Akbari et al., 1990).

\section{Weather Data}

Local full-year hourly weather data are required as input to the DOE-2 simulation program. The data used for this simulation were those for Toronto in the Weather Year for Energy Consumption (WYEC2) format. It is important to remark that this format represents normal rather than extreme weather conditions.

The direct energy impacts are simulated with the building-energy software DOE-2 and the standard WYEC2 climate data. The indirect energy impacts were estimated in a two-step process. First, a modified WYEC2 weather data was created to represent the impact of HIR strategies. Second, the prototypes were simulated with the modified weather tape to calculate the impact of the reduced ambient air temperature on cooling and heating energy use.

To quantify the ambient cooling from the indirect effect, a modified urban fabric (fraction of urban surfaces) is first created from the present fabric with increased urban vegetation, the planting of shade trees, and the use of reflective roofs and pavements. Second, the effect of the modified urban fabric on climate is simulated using the PSU/NCAR MM5 (Grell et al., 1994), from which a modified average dry-bulb air temperature is obtained from 15 locations within the boundaries of the model over 72-hour winter (Jan 15-17) and summer (July 15-17) episodes; discussed in detail by Taha et al. (2002). The modified temperature is then calculated for each hour of the year, using an algorithm based on a statistical analysis of temperature change $(\Delta \mathrm{T})$ as a function of solar intensity (I) (see Eq. 1). Because $\Delta \mathrm{T}$ is solely a function of solar intensity, $\Delta \mathrm{T}$ is zero during hours without sunlight. Finally, $\Delta \mathrm{T}$ is used to modify the standard WYEC2 weather data to create modified temperature data for the building energy simulations.

$\Delta \mathrm{T}\left[{ }^{\circ} \mathrm{C}\right]=-0.0018 \mathrm{I}\left[\mathrm{W} / \mathrm{m}^{2}\right]$

EQ. 1.

In Table 4.1, cooling and heating degree-days (base $18.3^{\circ} \mathrm{C}$ ) and the maximum air temperature have been tallied monthly for the standard and both modified WYEC2 weather data. The difference between the modified and the standard data is denoted by $\Delta \mathrm{T}$ in the table. Ambient cooling from urban fabric modification was observed mostly during June, July and August with 64, 106 and 91 fewer cooling degree-days during those months. On an annual basis, 324 cooling-degreedays were reduced by 45 . The effect on heating-degree-days was seen throughout the entire year; 
annually there were 54 more degree-days. The greatest reduction in maximum ambient air temperature was recorded as $1.7^{\circ} \mathrm{C}$ from a high of $34^{\circ} \mathrm{C}$ in July.

Table 4.1. Standard and modified Toronto WYEC2 weather data with cooling- and heatingdegree-days and maximum air temperature tallied monthly $(\Delta \mathrm{T}=$ modified $—$ standard $)$.

\begin{tabular}{|c|c|c|c|c|c|c|}
\hline \multirow[b]{2}{*}{ Month } & \multicolumn{2}{|c|}{$\begin{array}{l}\text { Cooling degree-days } \\
\text { [base } 18.3^{\circ} \mathrm{C} \text { ] }\end{array}$} & \multicolumn{2}{|c|}{$\begin{array}{l}\text { Heating degree-days } \\
\text { [base } 18.3^{\circ} \mathrm{C} \text { ] }\end{array}$} & \multicolumn{2}{|c|}{$\begin{array}{l}\text { Maximum air } \\
\text { temperature }\left[{ }^{\circ} \mathrm{C}\right]\end{array}$} \\
\hline & Standard & $\Delta$ & Standard & $\Delta$ & Standard & $\Delta$ \\
\hline January & 0 & 0 & 750 & 3 & 7 & 0.0 \\
\hline February & 0 & 0 & 671 & 5 & 5 & 0.0 \\
\hline March & 0 & 0 & 577 & 8 & 18 & -0.6 \\
\hline April & 2 & -1 & 359 & 11 & 24 & -1.1 \\
\hline May & 29 & -5 & 209 & 7 & 30 & -1.1 \\
\hline June & 64 & -10 & 68 & 9 & 33 & -1.1 \\
\hline July & 106 & -13 & 28 & 1 & 34 & -1.7 \\
\hline August & 91 & -11 & 40 & 1 & 32 & -0.6 \\
\hline September & 32 & -5 & 121 & 3 & 28 & -0.6 \\
\hline October & 1 & 0 & 269 & 6 & 21 & -0.6 \\
\hline November & 0 & 0 & 444 & 3 & 17 & -0.6 \\
\hline December & 0 & 0 & 662 & 2 & 8 & 0.0 \\
\hline Total & 324 & -45 & 4198 & 54 & & \\
\hline
\end{tabular}

Note: Maximum standard ambient air temperature and maximum modified temperature decrease are non-concurrent.

\section{Energy Prices}

Local residential and commercial electricity and natural gas rates were applied to the simulation results to obtain total annual energy use in dollars. Average commercial rates for electricity and natural gas consumption were available from a 1998 City of Toronto facility analysis (ICLEI 2001 ) and were $\$ 0.084 / \mathrm{kWh}$ and $\$ 5.54 / \mathrm{GJ}\left(\$ 0.206 / \mathrm{m}^{3}\right)$. Specific residential rates were obtained by inspecting the monthly utility bill for a typical house (Ligeti, 2002). The electricity rate was essentially the same as the commercial rates based on a comparison of Toronto Hydro Electric System rate schedules (THES, 2001). The gas rate was $\$ 10.84 /$ GJ (Total without customer charge $\$ 0.404 / \mathrm{m}^{3}$ : gas supply charge $\$ 0.202 / \mathrm{m}^{3}$, gas delivery charge $\$ 0.149 / \mathrm{m}^{3}$, and gas storage charge $\left.\$ 0.052 / \mathrm{m}^{3}\right)$. The price of gas has changed significantly over the last few years. To perform a preliminary analysis of the impact of the gas price on potential savings, we also calculated the net savings with a uniform price of $\$ 5.54 / \mathrm{GJ}$ for both residential and commercial buildings.

\section{DOE-2.1E Energy Simulations}

The simulations provided estimates of annual cooling- and heating-electricity use $\left[\mathrm{kWh} / 100 \mathrm{~m}^{2}\right]$, annual heating natural gas use $\left[\mathrm{GJ} / 100 \mathrm{~m}^{2}\right]$ and cooling peak-power demand $\left[\mathrm{kW} / 100 \mathrm{~m}^{2}\right]$. From the simulations, the annual total expenditures for cooling and heating energy $\left[\$ / 100 \mathrm{~m}^{2}\right]$ could then be calculated using local energy prices. Using the base case as a reference, annual energy 
and peak-power savings were determined for each HIR strategy. The base expenditure and demand and savings are presented in Tables 4.2(a, b, c). Table 4.2(a) shows the savings in absolute terms $\left[\mathrm{kWh} / 100 \mathrm{~m}^{2}, \mathrm{GJ} / 100 \mathrm{~m}^{2} \& \mathrm{~kW} / 100 \mathrm{~m}^{2}\right]$, Table $4.2(\mathrm{~b}$ and $\mathrm{c}$ ) show the savings in dollars with two prices for residential gas.

Base energy expenditures and peak-power demand were simulated using standard Toronto weather data for buildings with a dark roof (reflectance 0.2 ) and without shade trees or windshielding. Direct savings were simulated for a reflective roof (residential 0.5 and commercial 0.6), the placement of shade trees (residence 4, office 8 and retail 10) and wind-shielding. Indirect savings were simulated with modified weather data for the base case and each of the three direct cases. To estimate direct savings from increased roof reflectance $(\Delta \hat{a})$ other than those specified in Table 4 , multiply the savings by the ratio $\Delta \hat{\mathrm{a}} / 0.3$ for residences and $\Delta \hat{\mathrm{a}} / 0.4$ for commercial buildings ${ }^{\S}$. Linear interpolation can also be applied to direct shade tree savings. Savings will increase for buildings with less roof insulation than that specified in these prototypes (R-19 for old construction \& R-30 for new). Conversely, savings will decrease for those with more roof insulation. Savings in peak power make it clear that the required air-conditioner can be downsized when HIR strategies are considered.

The simulations predicted annual total energy savings of about 3-5\% from combined direct and indirect effects for old $17-22 \$ / 100 \mathrm{~m}^{2}$ and new $9 \$ / 100 \mathrm{~m}^{2}$ gas-heated single-family and rowhouse residences. This number increased to $10 \%$ for offices $\left[40 \$ / 100 \mathrm{~m}^{2}\right.$ for new and $100 \$ / 100 \mathrm{~m}^{2}$ for old] and $12 \%$ for retail buildings $\left[40 \$ / 100 \mathrm{~m}^{2}\right.$ for new and $100 \$ / 100 \mathrm{~m}^{2}$ for old]. Electricheated units did not fair so well, where savings of 0-2\% were observed for residences and 5-9\% for the office and retail buildings because the higher cost of electric heating than that of gas heating.

As expected, an annual natural gas deficit was found for all building types and in each HIR mitigation strategy with the exception of wind-shielding, since this measure reduces the heating requirements of a building. The annual gas deficit for combined direct and indirect effects was $2-6 \$ / 100 \mathrm{~m}^{2}$ for residences, $11-12 \$ / 100 \mathrm{~m}^{2}$ for offices and only $0-3 \$ / 100 \mathrm{~m}^{2}$ for retails.

Simulated peak power reduction was significant for all building types and strategies (windshielding was the exception). Combined direct and indirect peak-demand reduction in cooling electricity was $21-23 \%$ in residences and $13-16 \%$ in offices and retails. This translates into $0.57-0.61 \mathrm{~kW} / 100 \mathrm{~m}^{2}$ for pre-1980 residences, $0.33-0.40 \mathrm{~kW} / 100 \mathrm{~m}^{2}$ for $1980+$ residences, $0.60-$ $1.13 \mathrm{~kW} / 100 \mathrm{~m}^{2}$ for old and new offices, and $0.36-0.71 \mathrm{~kW} / 100 \mathrm{~m}^{2}$ for old and new retails.

\footnotetext{
${ }^{\S}$ Linear interpolation can be used to estimate savings or penalties for other net changes in roof reflectance ( $\left.\Delta \hat{\mathrm{a}}_{2}\right)$ than presented in the tables ( $\left.\Delta \hat{\mathrm{a}}_{1}\right)$ (Konopacki et al., 1997). Therefore, these results can be simply adjusted by the ratio $\Delta \hat{a}_{2} / \Delta \hat{a}_{1}$ to obtain estimates for other reflective roof scenarios.
} 
Table 4.2(a). Toronto simulated cooling and heating annual base expenditures and savings [electricity: $\mathrm{kWh} / 100 \mathrm{~m}^{2}$, gas: $\mathrm{GJ} / 100 \mathrm{~m}^{2}$ ], and peak-power demand and savings $\left[\mathrm{kW} / 100 \mathrm{~m}^{2}\right.$ ] from heat-island reduction strategies for residential and commercial buildings. Direct savings are from the use of solar-reflective roofs, strategic placement of deciduous shade trees and windshielding vegetation, and indirect savings include the impact of reduced ambient air temperature from a modified urban fabric. Simulations are presented per $100 \mathrm{~m}^{2}$ of air-conditioned roof area.

\begin{tabular}{|c|c|c|c|c|c|c|c|c|}
\hline \multirow{2}{*}{$\begin{array}{c}\text { Building type } \\
\& \\
\text { Mitigation strategy }\end{array}$} & \multicolumn{4}{|c|}{ Gas heat } & \multicolumn{2}{|c|}{$\begin{array}{c}\text { Electric heat } \\
\text { Electricity }\left(\mathrm{kWh} / 100 \mathrm{~m}^{2}\right)\end{array}$} & \multicolumn{2}{|c|}{$\begin{array}{c}\text { Gas \& electric heat } \\
\text { Peak power }\left(\mathrm{kW} / 100 \mathrm{~m}^{2}\right)\end{array}$} \\
\hline & $\begin{array}{l}\text { Pre- } \\
1980 \\
\end{array}$ & $1980+$ & Pre-1980 & $1980+$ & Pre-1980 & $1980+$ & Pre-1980 & $1980+$ \\
\hline $\begin{array}{l}\text { Residence: Single-Family } \\
\text { Base expenditure \& demand } \\
\text { Savings }\end{array}$ & 1057 & 629 & 75.0 & 49.3 & 14785 & 8391 & 2.70 & 1.71 \\
\hline Reflective roof savings & 94 & 52 & -0.9 & -0.5 & -62 & -20 & 0.12 & 0.08 \\
\hline Shade tree savings & 133 & 74 & -1.1 & -0.7 & -24 & -8 & 0.32 & 0.18 \\
\hline Wind shield savings & -32 & -25 & 2.5 & 1.2 & 379 & 134 & 0.00 & -0.02 \\
\hline Indirect savings & 88 & 51 & -0.8 & -0.5 & -100 & -59 & 0.13 & 0.09 \\
\hline $\begin{array}{l}\text { Combined savings } \\
\text { Residence: } \mathbf{R}-\mathbf{2 0 0 0}\end{array}$ & 283 & 152 & -0.2 & -0.6 & 193 & 47 & 0.57 & 0.33 \\
\hline $\begin{array}{l}\text { Base expenditure \& demand } \\
\text { Savings }\end{array}$ & $\mathrm{n} / \mathrm{a}$ & 440 & $\mathrm{n} / \mathrm{a}$ & 307.0 & $\mathrm{n} / \mathrm{a}$ & 5737 & $\mathrm{n} / \mathrm{a}$ & 1.27 \\
\hline Reflective roof savings & $\mathrm{n} / \mathrm{a}$ & 29 & $\mathrm{n} / \mathrm{a}$ & -5.0 & $\mathrm{n} / \mathrm{a}$ & -33 & $\mathrm{n} / \mathrm{a}$ & 0.05 \\
\hline Shade tree savings & $\mathrm{n} / \mathrm{a}$ & 57 & $\mathrm{n} / \mathrm{a}$ & -5.0 & $\mathrm{n} / \mathrm{a}$ & -9 & $\mathrm{n} / \mathrm{a}$ & 0.17 \\
\hline Wind shield savings & $\mathrm{n} / \mathrm{a}$ & -20 & $\mathrm{n} / \mathrm{a}$ & 6.0 & $\mathrm{n} / \mathrm{a}$ & 75 & $\mathrm{n} / \mathrm{a}$ & 0.00 \\
\hline Indirect savings & $\mathrm{n} / \mathrm{a}$ & 36 & $\mathrm{n} / \mathrm{a}$ & -4.0 & $\mathrm{n} / \mathrm{a}$ & -39 & $\mathrm{n} / \mathrm{a}$ & 0.02 \\
\hline $\begin{array}{l}\text { Combined savings } \\
\text { Residence: Row-House }\end{array}$ & $\mathrm{n} / \mathrm{a}$ & 101 & $\mathrm{n} / \mathrm{a}$ & -8.0 & $\mathrm{n} / \mathrm{a}$ & -5 & $\mathrm{n} / \mathrm{a}$ & 0.25 \\
\hline $\begin{array}{l}\text { Base expenditure \& demand } \\
\text { Savings }\end{array}$ & 1277 & 643 & 70.6 & 32.8 & 18509 & 8393 & 3.01 & 1.87 \\
\hline Reflective roof savings & 113 & 52 & -1.1 & -0.4 & -111 & -60 & 0.16 & 0.09 \\
\hline Shade tree savings & 127 & 75 & -0.8 & -0.5 & -34 & -11 & 0.29 & 0.22 \\
\hline Wind shield savings & -18 & -13 & 1.1 & 0.3 & 194 & 45 & -0.02 & -0.01 \\
\hline Indirect savings & 82 & 49 & -0.7 & -0.3 & -138 & -49 & 0.18 & 0.10 \\
\hline $\begin{array}{l}\text { Combined savings } \\
\text { Office }\end{array}$ & 305 & 164 & -1.6 & -0.8 & -90 & -75 & 0.61 & 0.40 \\
\hline $\begin{array}{l}\text { Base expenditure \& demand } \\
\text { Savings }\end{array}$ & 7276 & 3842 & 57.3 & 27.5 & 16934 & 8108 & 7.12 & 4.20 \\
\hline Reflective roof savings & 388 & 160 & -0.5 & -0.5 & 273 & 60 & 0.26 & 0.14 \\
\hline Shade tree savings & 637 & 260 & -0.9 & -0.8 & 485 & 129 & 0.43 & 0.23 \\
\hline Wind shield savings & -36 & -1 & 0.6 & 0.5 & 88 & 96 & 0.02 & 0.01 \\
\hline Indirect savings & 271 & 164 & -0.3 & -0.4 & 160 & 64 & 0.42 & 0.23 \\
\hline $\begin{array}{l}\text { Combined savings } \\
\text { Retail Store }\end{array}$ & 1260 & 583 & -1.2 & -1.3 & 1007 & 350 & 1.13 & 0.60 \\
\hline $\begin{array}{l}\text { Base expenditure \& demand } \\
\text { Savings }\end{array}$ & 7493 & 3356 & 31.1 & 10.1 & 12733 & 4944 & 4.90 & 2.63 \\
\hline Reflective roof savings & 522 & 200 & -0.5 & -0.6 & 429 & 102 & 0.26 & 0.14 \\
\hline Shade tree savings & 439 & 172 & -0.2 & -0.2 & 423 & 146 & 0.19 & 0.10 \\
\hline Wind shield savings & -42 & -13 & 1.1 & 0.8 & 138 & 111 & 0.02 & 0.01 \\
\hline Indirect savings & 258 & 133 & -0.3 & -0.3 & 179 & 82 & 0.24 & 0.11 \\
\hline Combined savings & 1177 & 492 & 0.0 & -0.3 & 1170 & 442 & 0.71 & 0.36 \\
\hline
\end{tabular}


Table 4.2(b). Toronto simulated cooling and heating annual base expenditures and savings $\left[\$ / 100 \mathrm{~m}^{2}\right]$ from heat-island reduction strategies for residential and commercial buildings (residential gas price of $\$ 5.54 / \mathrm{GJ})$. Direct savings are from the use of solar-reflective roofs, strategic placement of deciduous shade trees and wind-shielding vegetation, and indirect savings include the impact of reduced ambient air temperature from a modified urban fabric. Simulations are presented per $100 \mathrm{~m}^{2}$ of air-conditioned roof area.

\begin{tabular}{|c|c|c|c|c|c|c|c|c|}
\hline \multirow{3}{*}{$\begin{array}{c}\text { Building type } \\
\& \\
\text { Mitigation strategy }\end{array}$} & \multicolumn{4}{|c|}{ Annual energy and savings $\left(\$ / 100 \mathrm{~m}^{2}\right)$} & \multicolumn{4}{|c|}{ Annual energy $\left(\$ / 100 \mathrm{~m}^{2}\right)$ and savings $(\%)$} \\
\hline & \multicolumn{2}{|c|}{ Gas heat } & \multicolumn{2}{|c|}{ Electric heat } & \multicolumn{2}{|c|}{ Gas heat } & \multicolumn{2}{|c|}{ Electric heat } \\
\hline & Pre-1980 & $1980+$ & Pre-1980 & $1980+$ & Pre-1980 & $1980+$ & Pre-1980 & $1980+$ \\
\hline $\begin{array}{l}\text { Residence: Single-Family } \\
\text { Base expenditure \& demand } \\
\text { Savings }\end{array}$ & 504 & 325 & 1242 & 705 & 504 & 325 & 1242 & 705 \\
\hline Reflective roof savings & 2.5 & 1.5 & -5.2 & -1.7 & 0.5 & 0.5 & -0.4 & -0.2 \\
\hline Shade tree savings & 5.6 & 2.0 & -2.0 & -0.7 & 1.1 & 0.6 & -0.2 & -0.1 \\
\hline Wind shield savings & 11.6 & 4.4 & 31.8 & 11.2 & 2.3 & 1.4 & 2.6 & 1.6 \\
\hline Indirect savings & 2.7 & 1.3 & -8.4 & -5.0 & 0.5 & 0.4 & -0.7 & -0.7 \\
\hline Combined savings & 22.5 & 9.3 & 16.2 & 3.9 & 4.5 & 2.8 & 1.3 & 0.6 \\
\hline Residence: R-2000 & & & & & & & & \\
\hline $\begin{array}{l}\text { Base expenditure \& demand } \\
\text { Savings }\end{array}$ & $\mathrm{n} / \mathrm{a}$ & 216 & $\mathrm{n} / \mathrm{a}$ & 482 & $\mathrm{n} / \mathrm{a}$ & 216 & $\mathrm{n} / \mathrm{a}$ & 482 \\
\hline Reflective roof savings & $\mathrm{n} / \mathrm{a}$ & -0.3 & $\mathrm{n} / \mathrm{a}$ & -2.8 & $\mathrm{n} / \mathrm{a}$ & -0.1 & $\mathrm{n} / \mathrm{a}$ & -0.6 \\
\hline Shade tree savings & $\mathrm{n} / \mathrm{a}$ & 1.7 & $\mathrm{n} / \mathrm{a}$ & -0.7 & $\mathrm{n} / \mathrm{a}$ & 0.8 & $\mathrm{n} / \mathrm{a}$ & -0.2 \\
\hline Wind shield savings & $\mathrm{n} / \mathrm{a}$ & 1.5 & $\mathrm{n} / \mathrm{a}$ & 6.3 & $\mathrm{n} / \mathrm{a}$ & 0.7 & $\mathrm{n} / \mathrm{a}$ & 1.3 \\
\hline Indirect savings & $\mathrm{n} / \mathrm{a}$ & 0.8 & $\mathrm{n} / \mathrm{a}$ & -3.3 & $\mathrm{n} / \mathrm{a}$ & 0.4 & $\mathrm{n} / \mathrm{a}$ & -0.7 \\
\hline Combined savings & $\mathrm{n} / \mathrm{a}$ & 3.7 & $\mathrm{n} / \mathrm{a}$ & -0.5 & $\mathrm{n} / \mathrm{a}$ & 1.7 & $\mathrm{n} / \mathrm{a}$ & -0.1 \\
\hline Residence: Row-House & & & & & & & & \\
\hline $\begin{array}{l}\text { Base expenditure \& demand } \\
\text { Savings }\end{array}$ & 498 & 236 & 1555 & 705 & 498 & 236 & 1555 & 705 \\
\hline Reflective roof savings & 3.4 & 1.9 & -9.3 & -5.1 & 0.7 & 0.8 & -0.6 & -0.7 \\
\hline Shade tree savings & 5.8 & 3.6 & -2.9 & -0.9 & 1.2 & 1.5 & -0.2 & -0.1 \\
\hline Wind shield savings & 4.4 & 0.6 & 16.3 & 3.8 & 0.9 & 0.3 & 1.0 & 0.5 \\
\hline Indirect savings & 3.0 & 2.7 & -11.6 & -4.2 & 0.6 & 1.1 & -0.7 & -0.6 \\
\hline Combined savings & 16.7 & 8.9 & -7.5 & -6.3 & 3.3 & 3.8 & -0.5 & -0.9 \\
\hline Office & & & & & & & & \\
\hline $\begin{array}{l}\text { Base expenditure \& demand } \\
\text { Savings }\end{array}$ & 929 & 475 & 1422 & 681 & 929 & 475 & 1422 & 681 \\
\hline Reflective roof savings & 29.5 & 10.3 & 22.9 & 5.1 & 3.2 & 2.2 & 1.6 & 0.7 \\
\hline Shade tree savings & 48.5 & 17.5 & 40.8 & 10.9 & 5.2 & 3.7 & 2.9 & 1.6 \\
\hline Wind shield savings & 0.8 & 3.1 & 7.4 & 8.1 & 0.1 & 0.6 & 0.5 & 1.2 \\
\hline Indirect savings & 20.9 & 11.2 & 13.5 & 5.4 & 2.3 & 2.4 & 0.9 & 0.8 \\
\hline Combined savings & 99.6 & 42.1 & 84.6 & 29.4 & 10.7 & 8.8 & 5.9 & 4.3 \\
\hline Retail Store & & & & & & & & \\
\hline $\begin{array}{l}\text { Base expenditure \& demand } \\
\text { Savings }\end{array}$ & 802 & 338 & 1070 & 415 & 802 & 338 & 1070 & 415 \\
\hline Reflective roof savings & 40.7 & 13.0 & 36.0 & 8.6 & 5.1 & 3.9 & 3.4 & 2.1 \\
\hline Shade tree savings & 35.6 & 13.2 & 35.5 & 12.3 & 4.4 & 3.9 & 3.3 & 3.0 \\
\hline wind shield savings & 2.1 & 3.3 & 11.6 & 9.4 & 0.3 & 1.0 & 1.1 & 2.3 \\
\hline Indirect savings & 19.8 & 9.3 & 15.1 & 6.9 & 2.5 & 2.8 & 1.4 & 1.7 \\
\hline Combined savings & 98.9 & 39.4 & 98.2 & 37.1 & 12.3 & 11.7 & 9.2 & 8.9 \\
\hline
\end{tabular}


Table 4.2(c). Toronto simulated cooling and heating annual base expenditures and savings $\left[\$ / 100 \mathrm{~m}^{2}\right]$ from heat-island reduction strategies for residential and commercial buildings (residential gas price of $\$ 10.84 / G J)$. Direct savings are from the use of solar-reflective roofs, strategic placement of deciduous shade trees and wind-shielding vegetation, and indirect savings include the impact of reduced ambient air temperature from a modified urban fabric. Simulations are presented per $100 \mathrm{~m}^{2}$ of air-conditioned roof area.

\begin{tabular}{|c|c|c|c|c|c|c|c|c|}
\hline \multirow{3}{*}{$\begin{array}{c}\text { Building type } \\
\& \\
\text { Mitigation strategy }\end{array}$} & \multicolumn{4}{|c|}{ Annual energy and savings $\left(\$ / 100 \mathrm{~m}^{2}\right)$} & \multicolumn{4}{|c|}{ Annual energy $\left(\$ / 100 m^{2}\right)$ and savings $(\%)$} \\
\hline & \multicolumn{2}{|c|}{ Gas heat } & \multicolumn{2}{|c|}{ Electric heat } & \multicolumn{2}{|c|}{ Gas heat } & \multicolumn{2}{|c|}{ Electric heat } \\
\hline & Pre-1980 & $1980+$ & Pre-1980 & $1980+$ & Pre-1980 & $1980+$ & Pre-1980 & $1980+$ \\
\hline $\begin{array}{l}\text { Residence: Single-Family } \\
\text { Base expenditure \& demand } \\
\text { Savings }\end{array}$ & 898 & 584 & 1242 & 705 & 898 & 584 & 1242 & 705 \\
\hline Reflective roof savings & -2.5 & -1.1 & -5.2 & -1.7 & -0.3 & -0.2 & -0.4 & -0.2 \\
\hline Shade tree savings & 0.3 & -2.0 & -2.0 & -0.7 & 0.0 & -0.3 & -0.2 & -0.1 \\
\hline Wind shield savings & 25.1 & 10.6 & 31.8 & 11.2 & 2.8 & 1.8 & 2.6 & 1.6 \\
\hline Indirect savings & -1.7 & -1.6 & -8.4 & -5.0 & -0.2 & -0.3 & -0.7 & -0.7 \\
\hline Combined savings & 21.2 & 5.9 & 16.2 & 3.9 & 2.4 & 1.0 & 1.3 & 0.6 \\
\hline Residence: R-2000 & & & & & & & & \\
\hline $\begin{array}{l}\text { Base expenditure \& demand } \\
\text { Savings }\end{array}$ & $\mathrm{n} / \mathrm{a}$ & 386 & $\mathrm{n} / \mathrm{a}$ & 482 & $\mathrm{n} / \mathrm{a}$ & 386 & $\mathrm{n} / \mathrm{a}$ & 482 \\
\hline Reflective roof savings & $\mathrm{n} / \mathrm{a}$ & -2.9 & $\mathrm{n} / \mathrm{a}$ & -2.8 & $\mathrm{n} / \mathrm{a}$ & -0.8 & $\mathrm{n} / \mathrm{a}$ & -0.6 \\
\hline Shade tree savings & $\mathrm{n} / \mathrm{a}$ & -1.3 & $\mathrm{n} / \mathrm{a}$ & -0.7 & $\mathrm{n} / \mathrm{a}$ & -0.3 & $\mathrm{n} / \mathrm{a}$ & -0.2 \\
\hline Wind shield savings & $\mathrm{n} / \mathrm{a}$ & 4.6 & $\mathrm{n} / \mathrm{a}$ & 6.3 & $\mathrm{n} / \mathrm{a}$ & 1.2 & $\mathrm{n} / \mathrm{a}$ & 1.3 \\
\hline Indirect savings & $\mathrm{n} / \mathrm{a}$ & -1.3 & $\mathrm{n} / \mathrm{a}$ & -3.3 & $\mathrm{n} / \mathrm{a}$ & -0.3 & $\mathrm{n} / \mathrm{a}$ & -0.7 \\
\hline Combined savings & $\mathrm{n} / \mathrm{a}$ & -0.9 & $\mathrm{n} / \mathrm{a}$ & -0.5 & $\mathrm{n} / \mathrm{a}$ & -0.2 & $\mathrm{n} / \mathrm{a}$ & -0.1 \\
\hline Residence: Row-House & & & & & & & & \\
\hline $\begin{array}{l}\text { Base expenditure \& demand } \\
\text { Savings }\end{array}$ & 868 & 408 & 1555 & 705 & 868 & 408 & 1555 & 705 \\
\hline Reflective roof savings & -2.3 & -0.4 & -9.3 & -5.1 & -0.3 & -0.1 & -0.6 & -0.7 \\
\hline Shade tree savings & 1.2 & 1.1 & -2.9 & -0.9 & 0.1 & 0.3 & -0.2 & -0.1 \\
\hline Wind shield savings & 10.0 & 2.3 & 16.3 & 3.8 & 1.1 & 0.6 & 1.0 & 0.5 \\
\hline Indirect savings & -0.8 & 1.3 & -11.6 & -4.2 & -0.1 & 0.3 & -0.7 & -0.6 \\
\hline Combined savings & 8.2 & 4.3 & -7.5 & -6.3 & 0.9 & 1.0 & -0.5 & -0.9 \\
\hline Office & & & & & & & & \\
\hline $\begin{array}{l}\text { Base expenditure \& demand } \\
\text { Savings }\end{array}$ & 929 & 475 & 1422 & 681 & 929 & 475 & 1422 & 681 \\
\hline Reflective roof savings & 29.5 & 10.3 & 22.9 & 5.1 & 3.2 & 2.2 & 1.6 & 0.7 \\
\hline Shade tree savings & 48.5 & 17.5 & 40.8 & 10.9 & 5.2 & 3.7 & 2.9 & 1.6 \\
\hline Wind shield savings & 0.8 & 3.1 & 7.4 & 8.1 & 0.1 & 0.6 & 0.5 & 1.2 \\
\hline Indirect savings & 20.9 & 11.2 & 13.5 & 5.4 & 2.3 & 2.4 & 0.9 & 0.8 \\
\hline Combined savings & 99.6 & 42.1 & 84.6 & 29.4 & 10.7 & 8.8 & 5.9 & 4.3 \\
\hline Retail Store & & & & & & & & \\
\hline $\begin{array}{l}\text { Base expenditure \& demand } \\
\text { Savings }\end{array}$ & 802 & 338 & 1070 & 415 & 802 & 338 & 1070 & 415 \\
\hline Reflective roof savings & 40.7 & 13.0 & 36.0 & 8.6 & 5.1 & 3.9 & 3.4 & 2.1 \\
\hline Shade tree savings & 35.6 & 13.2 & 35.5 & 12.3 & 4.4 & 3.9 & 3.3 & 3.0 \\
\hline Wind shield savings & 2.1 & 3.3 & 11.6 & 9.4 & 0.3 & 1.0 & 1.1 & 2.3 \\
\hline Indirect savings & 19.8 & 9.3 & 15.1 & 6.9 & 2.5 & 2.8 & 1.4 & 1.7 \\
\hline Combined savings & 98.9 & 39.4 & 98.2 & 37.1 & 12.3 & 11.7 & 9.2 & 8.9 \\
\hline
\end{tabular}




\section{Air-Conditioned Roof Area Calculations}

The stock of air-conditioned $(\mathrm{a} / \mathrm{c})$ residential, office and retail buildings in the GTA were estimated for both pre-1980 and 1980+ construction vintages and both natural gas and electricity heating fuels. The 1996 population for the GTA was 4,218,465 persons residing in 1,488,370 households (STATCAN, 1996).

\section{Residential}

The total roof area for the stock of residences with $\mathrm{a} / \mathrm{c}$ was calculated from integrating data from the following sources: Statistics Canada (STATCAN, 1996), ICLEI Energy Services (ICLEI, 1997), Natural Resources Canada (NRCAN, 2001a) and the Survey of Household Energy Use (NRCAN, 1995). The residential stock was disaggregated into single-family, row-house (multifamily) and apartment structure types for pre-1980 and 1980+ construction vintages. The total residential air-conditioned roof area for the GTA [6] was estimated to be $39.8 \mathrm{Mm}^{2}\left(428 \mathrm{Mft}^{2}\right)$ (77\% single-family, 20\% row-house and 3\% apartment) from elements [1-5] arranged in Equation 2 and highlighted in Table 5.1. Since the apartment accounted for only $3 \%$ of the total a/c roof area in the residential sector a DOE-2 prototype was not developed.

[1] The number of occupied private dwellings (households) by period of construction and structural type were obtained from Statistics Canada for the 1996 census (STATCAN, 1996). The total number of dwellings listed are 1,488,370 and those built through 1980 are $72 \%$ or 1,074,000 and from 1981-1996 is $28 \%$ or 414,400 . The total number of single-family detached houses was $43 \%$ or 646,330 , row-house multi-family units (listed as other) were $28 \%$ or 421,675 and apartments (five or more stories) were $28 \%$ or 419,750 .

[2] The average floor area per dwelling unit was obtained from an analysis of housing in the city of Toronto for 1990 (ICLEI, 1997). The housing stock was disaggregated into single-detached, semi-detached, row-house and apartment units (apartments in mixed use were classified as rowhouse). For this analysis single- and semi-detached were combined into the category of singlefamily. The average floor area was listed as $128 \mathrm{~m}^{2}\left(1380 \mathrm{ft}^{2}\right), 97 \mathrm{~m}^{2}\left(1040 \mathrm{ft}^{2}\right)$ and $82 \mathrm{~m}^{2}\left(880 \mathrm{ft}^{2}\right)$ for the single-family, row-house and apartment dwellings, respectively. (Note that the average floor areas from NRCAN data are much larger.)

[3] The height of the building was identified from a statistical analysis of Natural Resources Canada data ${ }^{\S}$ (NRCAN, 2001a). The analysis shows that about $69.1 \%$ of buildings are singlefamily detached, $28.2 \%$ are row-houses, and $2.7 \%$ are double or attached houses. The number of stories of the houses was determined to be 1.8 for pre-1980 single-family, 2.0 for $1980+$ singlefamily, 2.2 for pre-1980 row-house and 2.4 for $1980+$ row-house. Apartments were assumed to be five story buildings.

[4] Air-conditioner equipment saturation for Ontario was found to be $46.5 \%, 64.1 \%$ for central a/c or heat pump units and $35.9 \%$ for window or room units (NRCAN, 1995). Also, the age of appliance was given to be 7.6 years for all air-conditioners, 6.9 years for central and 9.0 for window units. It was assumed that the single-family dwellings had only central a/c systems and the row-house/apartment dwellings had only window/room units.

\footnotetext{
$\S$ Natural Resources Canada has conducted a survey and compiled characteristic data for 1361 houses in the Toronto metropolitan area. The building data collected included: construction year, floor area, building foot print area, heating furnace type, furnace efficiency, furnace fuel, domestic hot water type, efficiency, fuel, type of house (single-family detached, attached, row houses), ceiling insulation, foundation wall insulation, walls insulation, number of stories, total occupancy, plan shape, basement heating temperature, main floor heating temperature, volume of house, infiltration rate, existence of central ventilation, and annual electricity and gas consumption. The data provided to us did not explicitly show any information of windows and cooling systems.
} 
[5] Natural gas was the dominant heating fuel and was surveyed in $86.0 \%$ of pre-1980 and $98.2 \%$ of $1980+$ single-family homes, as well as $92.3 \%$ of pre-1980 and $46.5 \%$ of $1980+$ row-houses. Similarly, electricity was surveyed in $6.2 \%$ of pre-1980 and $1.8 \%$ of $1980+$ single-family homes, as well as $4.8 \%$ of pre-1980 and $53.5 \%$ of $1980+$ row-houses (NRCAN, 2001a). Electricity is most likely used for electric resistance heaters and heat pumps. For the purpose of this analysis electric resistance heaters were considered exclusively in the row-house and apartment buildings.

[6] GTA A/C Roof Area residence $\left[\mathrm{Mm}^{2}\right]=[1] *[2] *[4] *[5] /[3] \quad$ EQ. 2.

R-2000 residences were not included in the GTA calculations because so few have been built. Natural Resources Canada (NRCAN, 2001b) states that since the program began in 1982, 8000 R-2000 houses have been certified. The GTA with $12.6 \%$ of the 1996 Canadian population (STATCAN, 1996) would thus have only 1000 R-2000 houses, about a tenth of $1 \%$ of the total housing stock of the GTA.

\section{Office and Retail}

The total roof area for the stock of office buildings and retail stores with a/c were calculated for pre1980 and 1980+ construction vintag es from integrating data from the above residential sector estimates and from Konopacki et al. (1997). Office and retail air-conditioned roof area for the GTA [10] was estimated to be $5.3 \mathrm{Mm}^{2}\left(57 \mathrm{Mft}^{2}\right)\left(1.9 \mathrm{Mm}^{2}\right.$ for offices and $3.4 \mathrm{Mm}^{2}$ for retail stores) from elements [6-9] arranged in Equation 3 and highlighted in Table 5.2.

[6] GTA residential a/c roof area for each vintage from equation 1 in $\mathrm{Mm}^{2}$.

[7] Konopacki et al. (1997) observed that the fraction of commercial to residential roof area was fairly constant when arranged by the general height of a city. Low-rise cities, such as the GTA, were found to have a fractional roof area (compared to the residential sector) of 4 and $7 \%$ for pre-1980 and 1980+ offices, and 10 and 5\% for pre-1980 and 1980+ retail stores.

[8] Air-conditioner equipment saturation was not available; therefore, it was assumed to be 100\% for both construction vintages, office and retail. This was also supported by Konopacki et al. (1997).

[9] Heating fuel type was not available; therefore, it was assumed to be $100 \%$ natural gas for both construction vintages, office and retail. This was also supported by Konopacki et al. (1997).

$[10]$ GTA A/C Roof Area office_retail $\left[\mathrm{Mm}^{2}\right]=[6] *[7] *[8] *[9] \quad$ EQ. 3. 
Table 5.1. Calculation of air-conditioned roof area $\left[\mathrm{Mm}^{2}\right]$ for residential buildings in the Greater Toronto Area.

\begin{tabular}{|c|c|c|c|c|}
\hline & Pre-1980 & $1980+$ & Total & Source \\
\hline $\begin{array}{l}1996 \text { Population } \\
\text { Persons [1000s] }\end{array}$ & - & - & 4218 & STATCAN, 1996 \\
\hline Residence: single-family & & & & \\
\hline [1] housing units [1000s] & 466 & 180 & 646 & STATCAN, 1996 \\
\hline [2] average floor area $\left[\mathrm{m}^{2} / \mathrm{hu}\right]$ & - & - & 128 & ICLEI, 1997: table 1 \\
\hline [3] building height [fls/hu] & 1.8 & 2 & - & NRCAN, 2001a \\
\hline [4] air-conditioner saturation [\%] & - & - & 68.7 & Calculation \\
\hline $\begin{array}{l}\text { Central or heat pump } \\
\text { [5] heating fuel [\%] }\end{array}$ & - & - & 100 & Assumption \\
\hline Natural gas & 86 & 98.2 & - & NRCAN, 2001a \\
\hline $\begin{array}{l}\text { Electricity } \\
{[6] \text { air-conditioned roof area }\left[\mathrm{Mm}^{2}\right]}\end{array}$ & 14 & 1.8 & - & NRCAN, 2001a + Assumption \\
\hline $\mathrm{W} /$ gas furnace & 19.6 & 7.8 & 27.4 & {$[1] *[2] *[4] *[5] /[3]$} \\
\hline $\mathrm{W} /$ heat pump & 3.2 & 0.2 & 3.4 & {$[1] *[2] *[4] *[5] /[3]$} \\
\hline Total & 22.8 & 8.0 & 30.8 & \\
\hline Residence: row-house & & & & \\
\hline [1] housing units [1000s] & 305 & 117 & 422 & \\
\hline [2] average floor area $\left[\mathrm{m}^{2} / \mathrm{hu}\right]$ & - & - & 97 & \\
\hline [3] building height $[\mathrm{fls} / \mathrm{hu}]$ & 2.2 & 2.4 & - & \\
\hline [4] air-conditioner saturation [\%] & - & - & 44.1 & \\
\hline $\begin{array}{l}\text { Window or room } \\
\text { [5] heating fuel [\%] }\end{array}$ & - & - & 100 & \\
\hline Natural gas & 92.3 & 46.5 & - & \\
\hline Electricity & 7.7 & 53.5 & - & \\
\hline$[6]$ air-conditioned roof area $\left[\mathrm{Mm}^{2}\right]$ & & & & \\
\hline $\mathrm{W} /$ gas furnace & 5.5 & 0.9 & 6.4 & \\
\hline $\mathrm{W} /$ heat pump & 0.5 & 1.1 & 1.6 & \\
\hline Total & 6.0 & 2.0 & 8.0 & \\
\hline Residence: apartment & & & & \\
\hline [1] housing units [1000s] & 303 & 117 & 420 & \\
\hline [2] average floor area $\left[\mathrm{m}^{2} / \mathrm{hu}\right]$ & - & - & 82 & \\
\hline [3] building height $[\mathrm{fls} / \mathrm{hu}]$ & 5 & 5 & - & \\
\hline [4] air-conditioner saturation [\%] & - & - & 14.8 & \\
\hline Window or room & - & - & 100 & \\
\hline [5] heating fuel [\%] & & & & \\
\hline Natural gas & 92.3 & 46.5 & - & \\
\hline Electricity & 7.7 & 53.5 & - & \\
\hline [6] air-conditioned roof area $\left[\mathrm{Mm}^{2}\right]$ & & & & \\
\hline $\mathrm{W} /$ gas furnace & 0.7 & 0.1 & 0.9 & \\
\hline W/ heat pump & 0.1 & 0.2 & 0.2 & \\
\hline Total & 0.8 & 0.3 & 1.1 & \\
\hline Residence: total & & & & \\
\hline [1] housing units [1000s] & 1074 & 414 & 1488 & \\
\hline [2] average floor area $\left[\mathrm{m}^{2} / \mathrm{hu}\right]$ & - & - & 94 & \\
\hline [4] air-conditioner saturation [\%] & - & - & 46.5 & NRCAN, 1995 \\
\hline Central or heat pump & - & - & 64.1 & NRCAN, 1995 \\
\hline $\begin{array}{l}\text { Window or room } \\
{[6] \text { air-conditioned roof area }\left[\mathrm{Mm}^{2}\right]}\end{array}$ & - & - & 35.9 & NRCAN, 1995 \\
\hline $\mathrm{W} /$ gas furnace & 25.7 & 8.8 & 34.5 & $\Sigma[6]$ single-family row-house apartment \\
\hline $\mathrm{W} /$ heat pump & 3.7 & 1.4 & 5.1 & $\Sigma[6]$ single-family_row-house_apartment \\
\hline Total & 29.4 & 10.2 & 39.6 & \\
\hline
\end{tabular}


Table 5.2. Calculation of air-conditioned roof area $\left[\mathrm{Mm}^{2}\right]$ for office and retail buildings in the Greater Toronto Area.

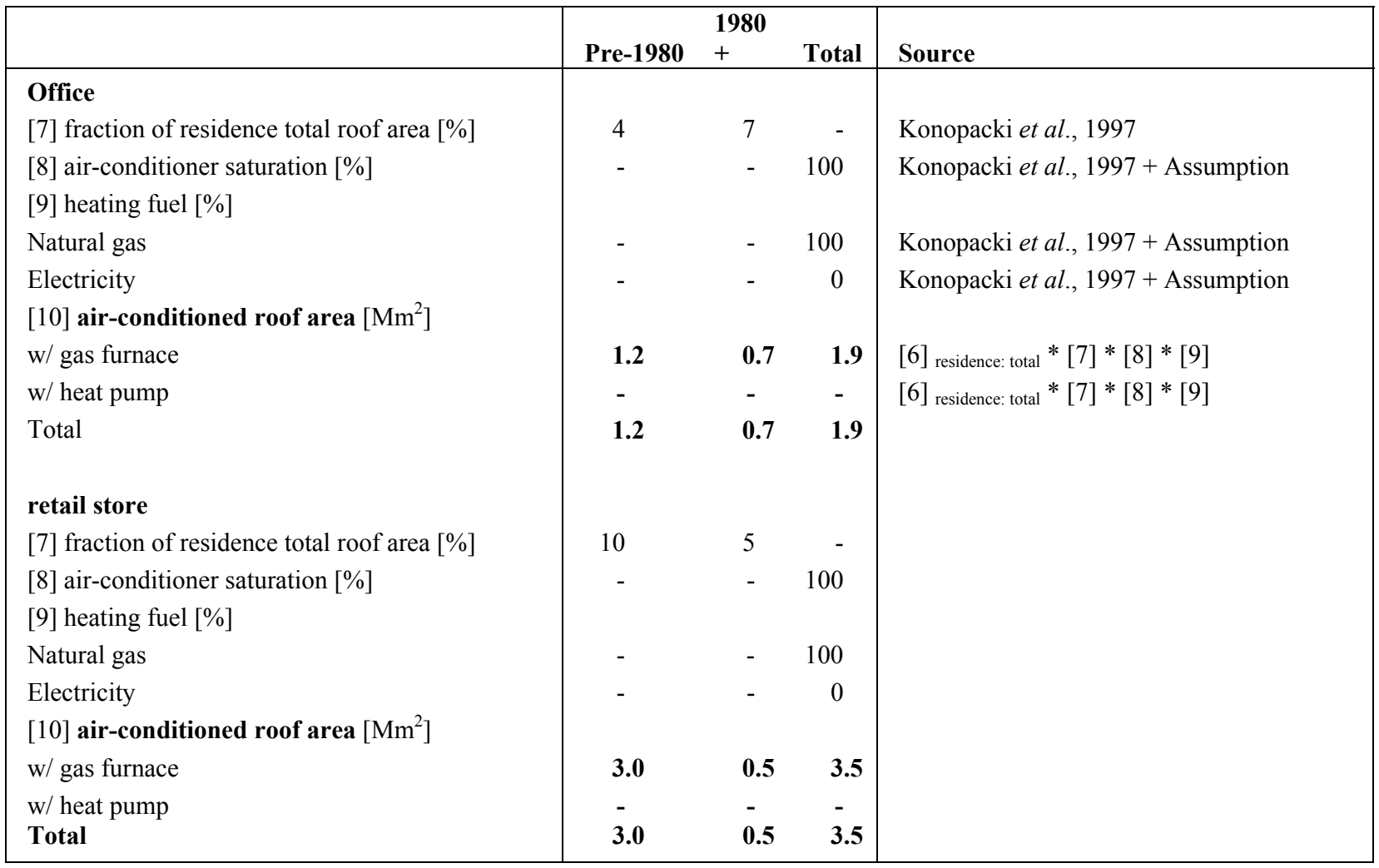

\section{Estimates of Savings for the Greater Toronto Area}

The potential metropolitan-wide benefits of Heat Island Reduction (HIR) strategies (i.e., shade trees, reflective roofs, reflective pavements and urban vegetation) in the GTA for residential, office and retail buildings with air-conditioning were estimated in the forms of annual energy savings, annual electricity savings, annual natural gas deficit, peak power avoided and annual carbon reduction.

The Greater Toronto Area has a population of over 4.2 million with nearly 1.5 million households and is situated inland, on the northwestern edge of Lake Ontario. The Toronto summer is hot and brief with a May through September cooling season, and the winter is cold from November through March (Average summer peak temperature is $34^{\circ} \mathrm{C}$ and average winter minimum temperature is $-24^{\circ} \mathrm{C}$. Typically, there are about 320 cooling degree-days and 4200 heating degree-days base $18.3^{\circ} \mathrm{C}$ ). Most residential buildings are two story and commercial buildings are low-rises. The saturation of air-conditioning is high in both residential and commercial buildings. The total roof area of residential, office and retail buildings with air-conditioning was 40, 1.9 and $3.5 \mathrm{Mm}^{2}$, respectively, and $75 \%$ built prior to 1980 .

Metropolitan-wide annual electricity savings [GWh], annual natural gas deficit [PJ], and peak power avoided [MW] are presented in Table 6.1 for residences, office buildings, retail stores, and the total for each HIR strategy. Metropolitan-wide estimates of annual energy savings [M\$] were calculated for residences, office buildings and retail stores. The estimates were obtained by combining the simulated energy and power savings from HIR strategies by the total air-conditioned roof area for each building type in the GTA. These results are presented in Table 6.2(a, b) 
with two prices for residential gas for each prototype by vintage and system type (i.e., for old and new building constructions and for gas and electric heat).

With uniform gas prices for commercial and residential buildings, annual electricity savings of $\$ 12.6 \mathrm{M}$ less a $10 \%$ natural gas deficit combine for a potential ratepayer benefit of over $\$ 11 \mathrm{M}$. Of that total, about $88 \%$ was from the direct impact roughly divided equally among reflective roofs, shade trees and wind-shielding, and the remainder $(12 \%)$ from the indirect impact of the cooler ambient air temperature. The residential sector accounts for over half (about 59\%) of the total, offices $13 \%$ and retail stores $27 \%$. Savings from cool roofs were about $20 \%$, shade trees $30 \%$, wind-shielding of tree $37 \%$, and indirect effect $12 \%$. These results are highly sensitive to the price of gas. Assuming a residential gas price of $\$ 10.84 / \mathrm{GJ}$ (gas price during December 2001), the net annual savings are reduced to $\$ 10 \mathrm{M}$; about $78 \%$ resulted from wind-shielding, $16 \%$ from shading by trees, and 5\% from cool roofs.

Potential annual electricity savings were estimated at about $150 \mathrm{GWh}$ or over $\$ 12 \mathrm{M}$, of which about $75 \%$ accrued from roofs and shade trees and only $2 \%$ from wind-shielding. The indirect effect from a modified urban fabric was $23 \%$. The savings distributed among buildings is similar to those cited above.

The potential annual natural gas deficit was estimated to be over 0.232 PJ or just under $\$ 1-2 \mathrm{M}$, with actual savings of over \$4-8M from wind-shielding and a combined penalty of under \$3$7 \mathrm{M}$. Residences accounted for about $94 \%$ of the gas deficit since these commercial buildings require very little heating.

Potential peak-power avoidance was estimated at about $250 \mathrm{MW}$ with about $74 \%$ attributed to the direct impacts (roofs about 24\%, shade trees 51\% and wind-shielding a small negative \%) and the remainder (26\%) to the indirect impact. About $83 \%$ of the avoided peak power resulted from the effects of the residences. The rest was shared by offices (7\%) and retail stores (9\%). 
Table 6.1. The Greater Toronto Area estimates of cooling and heating annual energy savings and avoided peak power from heat-island reduction strategies for residential and commercial buildings. Direct savings are from the use of solar-reflective roofs, strategic placement of deciduous shade trees and wind-shielding vegetation. Indirect savings include the effect of reduced ambient air temperature from a modified urban fabric.

\begin{tabular}{|c|c|c|c|c|c|c|c|c|}
\hline \multirow{3}{*}{$\begin{array}{c}\text { Building type } \\
\& \\
\text { Mitigation strategy }\end{array}$} & \multicolumn{4}{|c|}{ Gas heat } & \multirow{2}{*}{\multicolumn{2}{|c|}{$\begin{array}{c}\text { Electric heat } \\
\text { Electricity }(G W h)\end{array}$}} & \multirow{2}{*}{\multicolumn{2}{|c|}{$\begin{array}{l}\text { Gas \& electric heat } \\
\text { Peak power (MW) }\end{array}$}} \\
\hline & \multicolumn{2}{|c|}{ Electricity (GWh) } & \multicolumn{2}{|c|}{ Gas (PJ) } & & & & \\
\hline & Pre-1980 & $1980+$ & Pre- & $1980+$ & Pre- & $1980+$ & Pre-1980 & $1980+$ \\
\hline $\begin{array}{l}\text { Residence: Single-Family } \\
\text { Base expenditure \& demand } \\
\text { Savings }\end{array}$ & 207 & 49 & 14.8 & 3.8 & 467 & 16 & 615 & 137 \\
\hline Reflective roof savings & 18.4 & 4.1 & -0.19 & -0.04 & -2.0 & 0.0 & 27 & 6 \\
\hline Shade tree savings & 26.2 & 5.8 & -0.20 & -0.06 & -0.7 & 0.0 & 74 & 14 \\
\hline Wind shield savings & -6.3 & -2.0 & 0.51 & 0.09 & 12.0 & 0.2 & 0 & -1 \\
\hline Indirect savings & 17.3 & 4.0 & -0.17 & -0.04 & -3.2 & -0.1 & 29 & 7 \\
\hline $\begin{array}{l}\text { Combined savings } \\
\text { Apartment }\end{array}$ & 55.5 & 11.9 & -0.04 & -0.05 & 6.1 & 0.1 & 130 & 26 \\
\hline $\begin{array}{l}\text { Base expenditure \& demand } \\
\text { Savings }\end{array}$ & 8 & 1 & 0.4 & 0.0 & 17 & 16 & 22 & 5 \\
\hline Reflective roof savings & 0.7 & 0.0 & -0.01 & 0.00 & -0.1 & -0.1 & 1 & 0 \\
\hline Shade tree savings & 0.8 & 0.1 & -0.01 & 0.00 & 0.0 & 0.0 & 2 & 1 \\
\hline Wind shield savings & -0.1 & 0.0 & 0.01 & 0.00 & 0.2 & 0.1 & 0 & 0 \\
\hline Indirect savings & 0.5 & 0.0 & 0.00 & 0.00 & -0.1 & -0.1 & 1 & 0 \\
\hline $\begin{array}{l}\text { Combined savings } \\
\text { Residence: Row-House }\end{array}$ & 2.0 & 0.2 & -0.01 & 0.00 & -0.1 & -0.1 & 5 & 1 \\
\hline $\begin{array}{l}\text { Base expenditure \& demand } \\
\text { Savings }\end{array}$ & 70 & 6 & 3.9 & 0.3 & 86 & 94 & 179 & 38 \\
\hline Reflective roof savings & 6.2 & 0.5 & -0.06 & 0.00 & -0.5 & -0.7 & 9 & 2 \\
\hline Shade tree savings & 7.0 & 0.7 & -0.05 & 0.00 & -0.2 & -0.1 & 17 & 4 \\
\hline Wind shield savings & -1.0 & -0.1 & 0.06 & 0.00 & 0.9 & 0.5 & -1 & 0 \\
\hline Indirect savings & 4.5 & 0.5 & -0.04 & 0.00 & -0.6 & -0.6 & 11 & 2 \\
\hline Combined savings & 16.7 & 1.5 & -0.08 & -0.01 & -0.4 & -0.8 & 36 & 8 \\
\hline Office & & & & & & & & \\
\hline $\begin{array}{l}\text { Base expenditure \& demand } \\
\text { Savings }\end{array}$ & 88 & 29 & 0.7 & 0.2 & 0 & 0 & 86 & 31 \\
\hline Reflective roof savings & 4.7 & 1.2 & -0.01 & 0.00 & 0.0 & 0.0 & 3 & 1 \\
\hline Shade tree savings & 7.7 & 1.9 & -0.01 & -0.01 & 0.0 & 0.0 & 5 & 2 \\
\hline Wind shield savings & -0.4 & 0.0 & 0.01 & 0.00 & 0.0 & 0.0 & 0 & 0 \\
\hline Indirect savings & 3.3 & 1.2 & 0.00 & 0.00 & 0.0 & 0.0 & 5 & 2 \\
\hline Combined savings & 15.2 & 4.3 & -0.01 & -0.01 & 0.0 & 0.0 & 14 & 4 \\
\hline Retail Store & & & & & & & & \\
\hline $\begin{array}{l}\text { Base expenditure \& demand } \\
\text { Savings }\end{array}$ & 223 & 19 & 0.9 & 0.1 & 0 & 0 & 146 & 15 \\
\hline Reflective roof savings & 15.5 & 1.1 & -0.02 & 0.00 & 0.0 & 0.0 & 8 & 1 \\
\hline Shade tree savings & 13.1 & 1.0 & -0.01 & 0.00 & 0.0 & 0.0 & 6 & 1 \\
\hline Wind shield savings & -1.2 & -0.1 & 0.03 & 0.00 & 0.0 & 0.0 & 1 & 0 \\
\hline Indirect savings & 7.7 & 0.7 & -0.01 & 0.00 & 0.0 & 0.0 & 7 & 1 \\
\hline Combined savings & 35.0 & 2.7 & 0.00 & 0.00 & 0.0 & 0.0 & 21 & 2 \\
\hline Total & & & & & & & & \\
\hline $\begin{array}{l}\text { Base expenditure \& demand } \\
\text { Savings }\end{array}$ & 596 & 103 & 20.7 & 4.4 & 570 & 125 & 1048 & 226 \\
\hline Reflective roof savings & 45.5 & 6.9 & -0.27 & -0.05 & -2.6 & -0.8 & 48.4 & 10.0 \\
\hline Shade tree savings & 54.7 & 9.5 & -0.27 & -0.07 & -0.9 & -0.2 & 103.8 & 21.8 \\
\hline Wind shield savings & -9.1 & -2.2 & 0.61 & 0.11 & 13.0 & 0.8 & -0.3 & -1.4 \\
\hline Indirect savings & 33.3 & 6.5 & -0.22 & -0.05 & -3.9 & -0.8 & 53.5 & 11.5 \\
\hline Combined savings & 124.4 & 20.7 & -0.16 & -0.07 & 5.6 & -0.9 & 205 & 42 \\
\hline
\end{tabular}


Table 6.2a. The Greater Toronto Area estimates of cooling and heating annual base energy expenditures and savings $[\mathrm{M} \$]$ from heat-island reduction strategies for residential and commercial buildings (residential gas price of $\$ 5.54 / \mathrm{GJ}$ ). Direct savings are from the use of solarreflective roofs, strategic placement of deciduous shade trees and wind-shielding vegetation. Indirect savings include the effect of reduced ambient air temperature from a modified urban fabric.

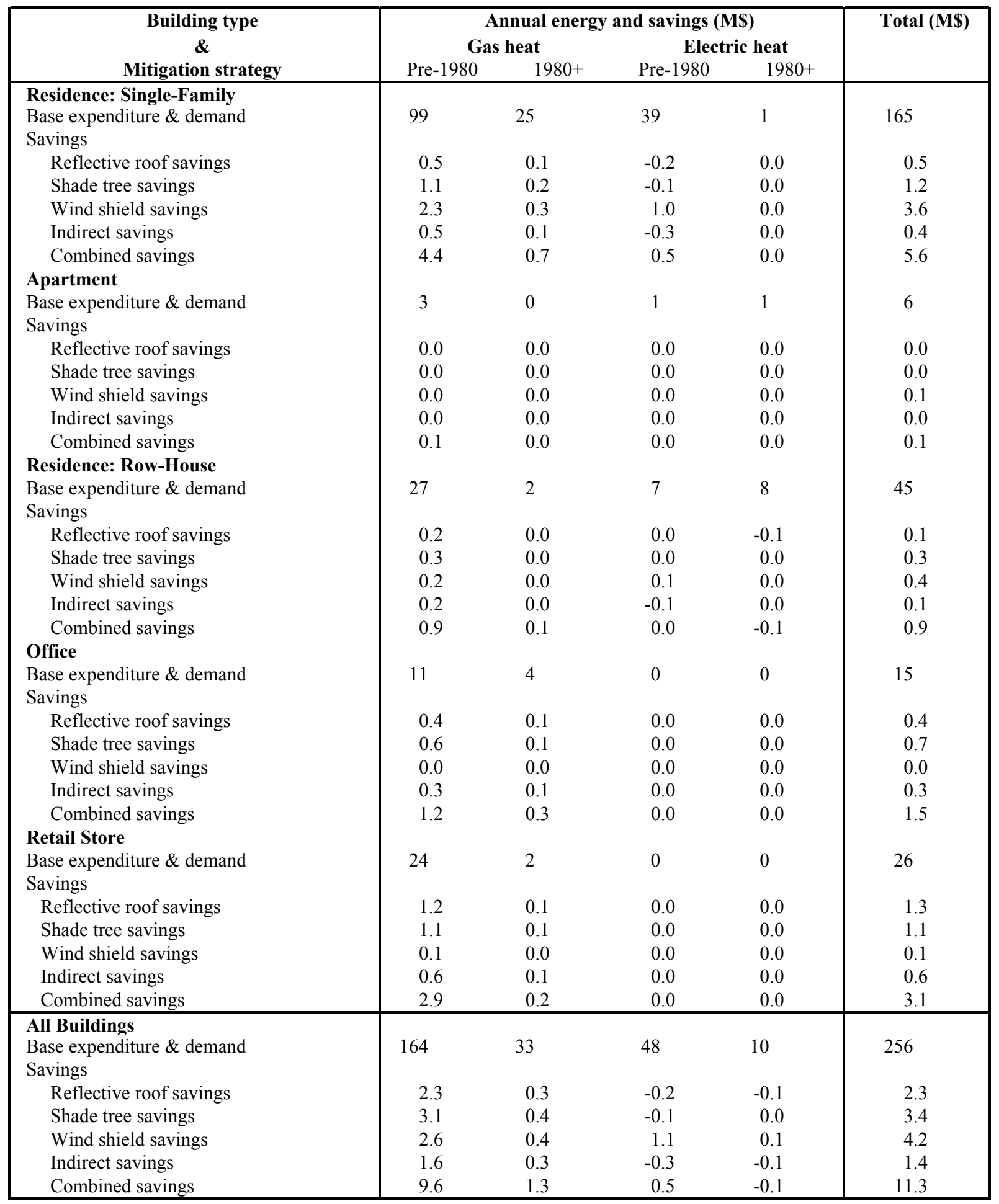


Table 6.2b. The Greater Toronto Area estimates of cooling and heating annual base energy expenditures and savings $[\mathrm{M} \$]$ from heat-island reduction strategies for residential and commercial buildings (residential gas price of $\$ 10.84 / \mathrm{GJ}$ ). Direct savings are from the use of solarreflective roofs, strategic placement of deciduous shade trees and wind-shielding vegetation. Indirect savings include the effect of reduced ambient air temperature from a modified urban fabric.

\begin{tabular}{|c|c|c|c|c|c|}
\hline \multirow{3}{*}{$\begin{array}{c}\text { Building type } \\
\& \\
\text { Mitigation strategy }\end{array}$} & \multicolumn{4}{|c|}{ Annual energy and savings (MS) } & \multirow[t]{3}{*}{ Total (MS) } \\
\hline & \multicolumn{2}{|c|}{ Gas heat } & \multicolumn{2}{|c|}{ Electric heat } & \\
\hline & Pre- 1980 & $1980+$ & Pre-1980 & $1980+$ & \\
\hline \multicolumn{6}{|l|}{ Residence: Single-Family } \\
\hline Base expenditure \& demand & 176 & 46 & 39 & 1 & 262 \\
\hline \multicolumn{6}{|l|}{ Savings } \\
\hline Reflective roof savings & -0.5 & -0.1 & -0.2 & 0.0 & -0.7 \\
\hline Shade tree savings & 0.1 & -0.2 & -0.1 & 0.0 & -0.2 \\
\hline Wind shield savings & 4.9 & 0.8 & 1.0 & 0.0 & 6.8 \\
\hline Indirect savings & -0.3 & -0.1 & -0.3 & 0.0 & -0.7 \\
\hline Combined savings & 4.2 & 0.5 & 0.5 & 0.0 & 5.1 \\
\hline \multicolumn{6}{|l|}{ Apartment } \\
\hline Base expenditure \& demand & 6 & 0 & 1 & 1 & 9 \\
\hline \multicolumn{6}{|l|}{ Savings } \\
\hline Reflective roof savings & 0.0 & 0.0 & 0.0 & 0.0 & 0.0 \\
\hline Shade tree savings & 0.0 & 0.0 & 0.0 & 0.0 & 0.0 \\
\hline Wind shield savings & 0.1 & 0.0 & 0.0 & 0.0 & 0.1 \\
\hline Indirect savings & 0.0 & 0.0 & 0.0 & 0.0 & 0.0 \\
\hline Combined savings & 0.1 & 0.0 & 0.0 & 0.0 & 0.0 \\
\hline \multicolumn{6}{|l|}{ Residence: Row-House } \\
\hline Base expenditure \& demand & 48 & 4 & 7 & 8 & 66 \\
\hline \multicolumn{6}{|l|}{ Savings } \\
\hline Reflective roof savings & -0.1 & 0.0 & 0.0 & -0.1 & -0.2 \\
\hline Shade tree savings & 0.1 & 0.0 & 0.0 & 0.0 & 0.1 \\
\hline Wind shield savings & 0.5 & 0.0 & 0.1 & 0.0 & 0.7 \\
\hline Indirect savings & 0.0 & 0.0 & -0.1 & 0.0 & -0.1 \\
\hline Combined savings & 0.4 & 0.0 & 0.0 & -0.1 & 0.4 \\
\hline \multicolumn{6}{|l|}{ Office } \\
\hline Base expenditure \& demand & 11 & 4 & 0 & 0 & 15 \\
\hline \multicolumn{6}{|l|}{ Savings } \\
\hline Reflective roof savings & 0.4 & 0.1 & 0.0 & 0.0 & 0.4 \\
\hline Shade tree savings & 0.6 & 0.1 & 0.0 & 0.0 & 0.7 \\
\hline Wind shield savings & 0.0 & 0.0 & 0.0 & 0.0 & 0.0 \\
\hline Indirect savings & 0.3 & 0.1 & 0.0 & 0.0 & 0.3 \\
\hline Combined savings & 1.2 & 0.3 & 0.0 & 0.0 & 1.5 \\
\hline \multicolumn{6}{|l|}{ Retail Store } \\
\hline Base expenditure \& demand & 24 & 2 & 0 & 0 & 26 \\
\hline \multicolumn{6}{|l|}{ Savings } \\
\hline Reflective roof savings & 1.2 & 0.1 & 0.0 & 0.0 & 1.3 \\
\hline Shade tree savings & 1.1 & 0.1 & 0.0 & 0.0 & 1.1 \\
\hline Wind shield savings & 0.1 & 0.0 & 0.0 & 0.0 & 0.1 \\
\hline Indirect savings & 0.6 & 0.1 & 0.0 & 0.0 & 0.6 \\
\hline Combined savings & 2.9 & 0.2 & 0.0 & 0.0 & 3.1 \\
\hline \multicolumn{6}{|l|}{ All Buildings } \\
\hline Base expenditure \& demand & 273 & 57 & 48 & 10 & 388 \\
\hline \multicolumn{6}{|l|}{ Savings } \\
\hline Reflective roof savings & 0.8 & 0.0 & -0.2 & -0.1 & 0.5 \\
\hline Shade tree savings & 1.7 & 0.0 & -0.1 & 0.0 & 1.6 \\
\hline Wind shield savings & 5.8 & 0.9 & 1.1 & 0.1 & 7.9 \\
\hline Indirect savings & 0.4 & 0.0 & -0.3 & -0.1 & 0.0 \\
\hline Combined savings & 8.7 & 1.0 & 0.5 & -0.1 & 10.1 \\
\hline
\end{tabular}




\section{Discussion}

This analysis included the direct and indirect effects of three heat-island reduction measures (shade trees, reflective roofs, and reflective paved surfaces) on heating- and cooling-energy use of several prototypical residential and commercial buildings. The prototypical savings were then extrapolated to obtain savings potentials for the Greater Toronto Area. In reviewing the results of this analysis, the following should be considered:

1. Reflective roofs and shade trees reduce summer cooling-energy use and also potentially increase winter heating-energy use. The net savings (\$ savings in cooling energy use - \$ penalties in heating-energy use) is highly sensitive to prices of cooling- and heating-energy fuels. In the residential building prototypes cooled and heated with electricity, we found that most of the cooling-energy savings are written off by the penalties in heating-energy use). Since reflective roofs and shade trees affect the energy performance of a building typically for 20 30 years, a better understanding of long-term trends in energy prices would lead to better estimates of savings potentials.

2. Trees affect the energy use of a building by shading and wind shielding. Our capabilities to simulate the shading effects of trees are typically more refined than simulating the windshielding effects. Future studies to investigate further the wind-shielding effects of trees on heating-energy use would improve the current estimates.

3. DOE-2 currently underestimates the cooling-energy saving potentials of reflective roofs by as much as a factor of two. Hence, the saving potentials shown for reflective roofs should be considered as conservative. Furthermore, during the winter, some of the roofs are covered with snow. Hence the heating penalties of reflective roofs are potentially overestimated. A few monitoring and demonstration projects at the GTA would lead to a better understanding of the actual saving potentials in the region.

4. Although the simulations were performed for office, retail store, and residential prototypes, the results are normalized by roof area for each prototype. These results can be used to estimate savings potentials in other building types. For instance, one can comfortably estimate savings for a hospital based on the results obtained for office buildings.

5. The total roof area for commercial buildings in the GTA was estimated using an approach based on the population and the residential roof area. A more direct estimate of the actual roof area for commercial buildings can improve the accuracy of the estimates.

6. The indirect saving potentials were only a small fraction of total potential savings. Hence, for energy saving potentials consideration, reflective roofs and shade trees that save energy both directly and indirectly should be given a higher priority than reflective pavements that only save energy indirectly.

\section{Conclusion}

In this study, we have investigated the potential of Heat Island Reduction (HIR) strategies (i.e., solar-reflective roofs, shade trees, wind-shielding, reflective pavements and urban vegetation) to reduce cooling energy use in buildings in the Greater Toronto Area, Canada. The impact of both direct effect (reducing heat gain through the building shell) and indirect effect (reducing the ambient air temperature) was addressed.

To perform this analysis, we identified three building types that offer the most savings potential: residence (single-family and row-house), office and retail store. Each building type was characterized in detail by pre-1980 (old) or 1980+ (new) construction vintage and with natural gas or 
electricity as heating fuel. We defined prototypical characteristics for each building type and simulated the impact of HIR strategies on building cooling and heating energy use and peakpower demand using the DOE-2.1E model and Toronto WYEC2 weather data. Our simulations included the impact of HIR strategies outlined below.
A. Use of solar-reflective roofing material on building [direct effect].
B. Placement of deciduous shade trees near south and west walls of building [direct effect].
C. Placement of coniferous wind-shielding vegetation near building [direct effect].
D. Urban reforestation with reflective building surfaces and pavements [indirect effect].
E. Combination of strategies A through D [direct and indirect effects].

We then estimated the total roof area of air-conditioned residential, office and retail buildings in the GTA to scale the energy simulations in order to calculate the metropolitan-wide impact of HIR strategies.

Toronto is a metropolitan area of over 4.2 million with nearly 1.5 million households and is situated inland, on the northwestern edge of Lake Ontario. The Toronto summer is hot and brief with a May through September cooling season, and the winter is cold from November through March (Average summer peak temperature is $34^{\circ} \mathrm{C}$ and average winter minimum temperature is $-24^{\circ} \mathrm{C}$. Typically, there are about 320 cooling degree-days and 4200 heating degree-days base $18.3^{\circ} \mathrm{C}$ ). Most residential buildings are one story and commercial buildings are low-rises. The saturation of air-conditioning is high in both residential and commercial buildings. The total roof area of residential, office and retail buildings with air-conditioning was 428,20 and $37 \mathrm{Mft}^{2}$, respectively, and $75 \%$ built prior to 1980 .

The simulations predicted annual total energy savings of about 3-5\% from combined direct and indirect effects for old $17-22 \$ / 100 \mathrm{~m}^{2}$ and new $9 \$ / 100 \mathrm{~m}^{2}$ gas-heated single-family and rowhouse residences. This number increased to $10 \%$ for offices $\left[40 \$ / 100 \mathrm{~m}^{2}\right.$ for new and $100 \$ / 100 \mathrm{~m}^{2}$ for old] and $12 \%$ for retail stores $\left[40 \$ / 100 \mathrm{~m}^{2}\right.$ for new and $100 \$ / 100 \mathrm{~m}^{2}$ for old]. Electric-heated units did not fair so well, where savings of $0-2 \%$ were observed for residences and $5-9 \%$ for offices and retail stores because the electric heating penalty is more expensive than that of gas.

As expected, an annual natural gas deficit was found for all building types and in each HIR mitigation strategy with the exception of wind-shielding, since this measure reduces the heating requirements of a building. The annual gas deficit for combined direct and indirect effects was $2-6 \$ / 100 \mathrm{~m}^{2}$ for residences, $11-12 \$ / 100 \mathrm{~m}^{2}$ for offices and only $0-3 \$ / 100 \mathrm{~m}^{2}$ for retails.

Simulated peak power reduction was significant for all building types and strategies (windshielding was the exception). Combined direct and indirect peak-demand reduction in cooling electricity was $21-23 \%$ in residences and $13-16 \%$ in offices and retails. This translates into $0.57-0.61 \mathrm{~kW} / 100 \mathrm{~m}^{2}$ for pre-1980 residences, $0.33-0.40 \mathrm{~kW} / 100 \mathrm{~m}^{2}$ for $1980+$ residences, $0.60-$ $1.13 \mathrm{~kW} / 100 \mathrm{~m}^{2}$ for old and new offices, and $0.36-0.71 \mathrm{~kW} / 100 \mathrm{~m}^{2}$ for old and new retails.

The potential metropolitan-wide benefits assume the full implementation of HIR measures and were calculated in the form of annual energy savings [M\$], annual electricity savings [GWh \& $\mathrm{M} \$$ ], annual natural gas deficit [PJ \& M\$], and avoided peak power [MW].

The potential metropolitan-wide benefits assume full implementation of HIR measures and were calculated in the form of annual energy savings [M\$], annual electricity savings [GWh \& M\$], annual natural gas deficit [PJ \& M\$], and avoided peak power [MW].

Results show potential annual energy savings of over $\$ 11 \mathrm{M}$ (with uniform residential and commercial electricity and gas prices of $\$ 0.084 / \mathrm{kWh}$ and $\$ 5.54 / \mathrm{GJ}$ ) could be realized by ratepayers from the combined direct and indirect effects of HIR strategies. Of that total, about $88 \%$ was 
from the direct impact roughly divided equally among reflective roofs, shade trees and windshielding, and the remainder (12\%) from the indirect impact of the cooler ambient air temperature. The residential sector accounts for over half (about 59\%) of the total, offices $13 \%$ and retail stores $27 \%$. Savings from cool roofs were about $20 \%$, shade trees $30 \%$, wind-shielding of tree $37 \%$, and indirect effect $12 \%$. These results are highly sensitive to the price of gas. Assuming a residential gas price of $\$ 10.84 / \mathrm{GJ}$ (gas price during December 2001), the net annual savings are reduced to $\$ 10 \mathrm{M}$; about $78 \%$ resulted from wind-shielding, $16 \%$ from shading by trees, and $5 \%$ from cool roofs.

Potential annual electricity savings were estimated at about $150 \mathrm{GWh}$ or over $\$ 12 \mathrm{M}$, of that about $75 \%$ accrued from roofs and shade trees and only $2 \%$ from wind-shielding. The indirect effect from a modified urban fabric was $23 \%$. The savings distributed among buildings is similar to those cited above.

The potential annual natural gas deficit was estimated to be over 0.23 PJ or just under $\$ 1-2 \mathrm{M}$, with actual savings of over \$4-8M from wind-shielding and a combined penalty of under \$3$7 \mathrm{M}$. Residences accounted for about $94 \%$ of the gas deficit since these commercial buildings require very little heating.

Potential avoided peak-power was estimated at about $250 \mathrm{MW}$ with about $74 \%$ attributed to the direct impacts (roofs about 24\%, shade trees $51 \%$ and wind-shielding a small negative \%) and the remainder $(26 \%)$ to the indirect impact. About $83 \%$ of the avoided peak power was because of the effects of the residences and the rest shared by offices $(7 \%)$ and retail stores $(9 \%)$.

By their nature, the results of this study are preliminary. The objective of the project was to perform a preliminary analysis and to develop a database of potential energy and peak-demand savings from the implementation of heat-island-reduction technologies (i.e., cool roofs, shade trees, and cool pavements). To perform such a study, we focused on three building types (residential, office, and retail) that offer the highest potential savings for the GTA. We focused on these three building types primarily because they constitute over $90 \%$ of the floor area of the total building stock in the GTA. The HIR technologies are also very effective on other building types such as hospitals, schools, restaurants, grocery stores, etc. However, the potential savings from these other buildings only contribute a few percent of additional savings for the entire metropolitan Toronto. 


\section{References}

Akbari, H., A. Rosenfeld, and H. Taha. 1990. "Summer Heat Islands, Urban Trees, and White Surfaces," ASHRAE Transactions, 96(1).

Akbari, H. and H. Taha. 1992. "The Impact of Trees and White Surfaces on Residential Heating and Cooling Energy Use in Four Canadian Cities." Energy 17:141-150.

Akbari, H., S. Bretz, D. Kurn and J. Hanford. 1997a. "Peak Power and Cooling Energy Savings of High-Albedo Roofs.” Energy and Buildings 25:117-126.

Akbari, H., D. Kurn, S. Bretz and J. Hanford. 1997b. "Peak Power and Cooling Energy Savings of Shade Trees." Energy and Buildings 25:139-148.

Akbari, H., S. Konopacki, C. Eley, B. Wilcox, M. Van Geem and D. Parker. 1998. "Calculations for Reflective Roofs in Support of Standard 90.1.” ASHRAE Transactions 104(1):984995.

Akbari, H. and L. Rainer. 2000. "Measured Energy Savings from the Application of Reflective Roofs in 3 AT\&T Regeneration Buildings.” Lawrence Berkeley National Laboratory Report LBNL-47075. Berkeley, CA.

Akbari, H., M. Pomerantz and H. Taha. 2001 "Cool Surfaces and Shade Trees to Reduce Energy Use and Improve Air Quality in Urban Areas.” Solar Energy 70(3):295-310.

Akridge, J. 1998. "High-Albedo Roof Coatings-Impact on Energy Consumption." ASHRAE Technical Data Bulletin 14(2).

Boutwell, C. and Y. Salinas. 1986. "Building for the Future-Phase I: An Energy Saving Materials Research Project." Oxford: Mississippi Power Co., Rohm and Haas Co. and the University of Mississippi.

Bretz, S. and H. Akbari. 1997. "Long-Term Performance of High-Albedo Roof Coatings." Energy and Buildings 25:159-167.

Building Energy Simulation Group (BESG). 1990. "Overview of the DOE-2 Building Energy Analysis Program, Version 2.1D.” Lawrence Berkeley National Laboratory Report LBL19735, Rev. 1. Berkeley, CA.

Cool Roofing Materials Database (CRMD). 2001. http://eetd.lbl.gov/coolroof. Lawrence Berkeley National Laboratory. Berkeley, CA.

Energy Information Administration (EIA). 1997. DOE/EIA-0383(97) Annual Energy Outlook 1997. Tables A8 and A19. Washington, DC.

Gartland, L., S. Konopacki and H. Akbari. 1996. "Modeling the Effects of Reflective Roofing." ACEEE Summer Study on Energy Efficiency in Buildings 4:117-124. Pacific Grove, CA.

Grell, G., J. Dudhia and D. Stauffer. 1994. "A Description of the Fifth-Generation Penn State/NCAR Mesoscale Model (MM5)." National Center for Atmospheric Research Technical Note NCAR/TN-398 + STR. Boulder, CO.

Henderson, H. 1998. "Part Load Curves for Use in DOE-2." Draft report prepared for Lawrence Berkeley National Laboratory and Florida Solar Energy Center. CDH Energy Corp. Cazenovia, NY. January 16, 1998.

Hildebrandt, E., W. Bos and R. Moore. 1998."Assessing the Impacts of White Roofs on Building Energy Loads" ASHRAE Technical Data Bulletin 14(2). 
International Council for Local Environmental Initiatives Energy Services (ICLEI). 1997. "Realizing Toronto's Target for Greenhouse Gas Emission Reductions - Current Trends and Outlook." Torrie Smith Associates. Toronto, Ontario.

International Council for Local Environmental Initiatives Energy Services (ICLEI). 2001. "Summary Report Opportunities for Budget Cost Savings in the City of Toronto's Corporate Facilities - Technical Reference: Data and Analysis." Toronto, Ontario.

Jessup, P. 2000. Private communication. Toronto Atmospheric Fund, Toronto, Canada.

Konopacki, S., H. Akbari, M. Pomerantz, S. Gabersek and L. Gartland. 1997. "Cooling Energy Savings Potential of Light-Colored Roofs for Residential and Commercial Buildings in 11 U.S. Metropolitan Areas." Lawrence Berkeley National Laboratory Report LBNL39433. Berkeley, CA.

Konopacki, S., H. Akbari, L. Gartland and L. Rainer. 1998. "Demonstration of Energy Savings of Cool Roofs.” Lawrence Berkeley National Laboratory Report LBNL-40673. Berkeley, CA.

Konopacki, S. and H. Akbari. 1998a. "Simulated Impact of Roof Surface Solar Absorptance, Attic, and Duct Insulation on Cooling and Heating Energy Use in Single-Family New Residential Buildings." Lawrence Berkeley National Laboratory Report LBNL-41834. Berkeley, CA.

Konopacki, S. and H. Akbari. 1998b. "Demonstration of Energy Savings of Cool Roofs: Phase II.” Lawrence Berkeley National Laboratory-Heat Island Group Technical Note. Berkeley, CA.

Konopacki, S. and H. Akbari. 2000. "Energy Savings Calculations for Heat Island Reduction Strategies in Baton Rouge, Sacramento and Salt Lake City." Lawrence Berkeley National Laboratory Report LBNL-42890. Berkeley, CA.

Konopacki, S. and H. Akbari. 2001. "Measured Energy Savings and Demand Reduction from a Reflective Roof Membrane on a Large Retail Store in Austin." Lawrence Berkeley National Laboratory Report LBNL-47149. Berkeley, CA.

Ligeti, E. 2002. Private communication. Obtained copy of electricity and gas utility bills for a single-family residence. Toronto Atmospheric Fund, Toronto, Canada.

National Appliance Energy Conservation Act of 1987 (NAECA). 1987. DOE Publication. www.eren.doe.gov/buildings/codes_standards/notices/pdfs/furn_boiler_notice.pdf. U.S. Department of Energy, Washington, D.C.

Natural Resources Canada (NRCAN). 1995. “1993 Survey of Household Energy Use.” Energy Publications. Ottawa, Ontario.

Natural Resources Canada (NRCAN). 2001a. "Toronto Survey of 1361 Homes.” Office of Energy Efficiency, Ottawa, Ontario.

Natural Resource Canada (NRCAN). 2001b. "R-2000 Program." Office of Energy Efficiency. http://oee.nrcan.gc.ca/english/newhouses_r2000.cfm.

Parker, D., J. Sonne and J. Sherwin. 1997. "Demonstration of Cooling Savings of Light Colored Roof Surfacing in Florida Commercial Buildings: Retail Strip Mall.” Florida Solar Energy Center Report FSEC-CR-964-97. Cocoa, Fl.

Parker, D., J. Huang, S. Konopacki, L. Gartland, J. Sherwin and L. Gu. 1998a. "Measured and Simulated Performance of Reflective Roofing Systems in Residential Buildings." ASHRAE Transactions 104(1):963-975. 
Parker, D., J. Sherwin and J. Sonne. 1998b. "Measured Performance of a Reflective Roofing System in a Florida Commercial Building." ASHRAE Technical Data Bulletin 14(2).

Parker, D. and K. Sheinkopf. 1999. "Cool Home Features Bring Peak Energy Savings.” Home Energy 16:22-27.

Sherman, M., D. Wilson and D. Kiel. 1986. "Variability in Residential Air Leakage." Measured Air Leakage in Buildings ASTM STP-904. Philadelphia, PA.

Statistics Canada (STATCAN). 1996. http://www.statcan.ca.

Taha, H., S. Konopacki and S. Gabersek. 1996. "Modeling the Meteorological and Energy Effects of Urban Heat Islands and Their Mitigation: a 10 Region Study." Lawrence Berkeley National Laboratory Draft Report LBNL-39335. Berkeley, CA.

Taha, H., S.C. Chang, and H. Akbari. 2002. "Air Quality Impacts of Heat Island Reduction Strategies in Toronto, Canada." Lawrence Berkeley National Laboratory Draft Report LBNL-49210. Berkeley, CA.

Toronto Hydro Electric System (THES). 2001. "Rates." www.torontohydro.com/ electricsystem/business/rates.htm. www.torontohydro.com/electricsystem/residential/rates.htm

U.S. Department of Energy (U.S.DOE). 2001. "Choosing or Upgrading Your Central Airconditioner." Office of Building Technology, State and Community Programs." http://www.eren.doe.gov/buildings/heatcool_cenair.html.

Winklemann, F., B. Birdsall, W. Buhl, K. Ellington and A. Erdem. 1993. "DOE-2 Supplement Version 2.1E.” Lawrence Berkeley National Laboratory Report LBNL-34947. Berkeley, CA. 


\section{Appendix A. Building Information Data Sources}

We contacted various agencies and individuals in regards to obtaining building data for the Greater Toronto area. In general, obtaining detailed building characteristics data proved to be more difficult than anticipated. Two sources provided detailed data for the housing sector. To date, we have not identified any relevant data for the commercial sector in Toronto.

Natural Resources Canada (NRCAN, 2001a) has conducted a survey and compiled characteristic data for 1361 houses in the Greater Toronto Area. The building data collected included: construction year, floor area, building foot print area, heating furnace type, furnace efficiency, furnace fuel, domestic hot water type, efficiency, fuel, type of house (single-family detached, attached, row-houses), ceiling insulation, foundation wall insulation, walls insulation, number of stories, total occupancy, plan shape, basement heating temperature, main floor heating temperature, volume of house, infiltration rate, existence of central ventilation, and annual electricity and gas consumption. The data provided to us does not explicitly show any information of windows and cooling systems; we have contacted NRCAN regarding this additional data.

We performed a statistical analysis of the NRCAN data; the results are summarized in Table A.1. NRCAN database shows that about $69.1 \%$ of buildings are single-family detached, $28.2 \%$ are row houses, and $2.7 \%$ are double or attached houses. These data clearly support development of two prototypes of single-family detached and row houses. In addition, $87.1 \%$ of houses are heated with gas, $7.8 \%$ with electricity, and $5.1 \%$ with oil. About $16.9 \%$ of houses are singlestory, $60.6 \%$ two stories, and $20.5 \%$ two and a half or three stories. Finally, $97.9 \%$ of buildings have no mechanical ventilation systems.

The integrity and insulation level in houses varies with age (see Figure A.1). It appears that most houses have lower insulation both on ceilings and walls prior to $1970 \mathrm{~s}$. We partitioned the data for Pre-1980 and 1980+ for an analysis of housing insulation. Indeed, the average roof and wall insulation for the $1980+$ period is larger than the Pre-1980 period. We also observe that the infiltration rate (as measured by Air Change per Hour, ACH) is much lower for 1980+ than Pre1980, indicating better-built and tighter houses. The heating furnace efficiency is also higher for $1980+$ than Pre-1980 period. Most houses are heated with gas, except $1980+$ row houses that are about $50 \%$ heated with gas and $50 \%$ electricity.

Another data source for residential buildings was Akbari et al. (1992). This study analyzed and estimated the impact of trees and reflective roofs on residential heating and cooling energy use in four Canadian cities. The study also summarized detailed building characteristics data for singlefamily one-story detached houses, single-family two-story detached houses, single-family onestory detached R-2000 houses, single-family two-story detached R-2000 houses, two-story row houses, and two-story R-2000 row houses. The characteristics of these prototypes are listed in Tables A.2-4.

The building characteristic data available from NRCAN database and Akbari et al. (1992) are sufficient to define prototypical-building description. The prototypes to be developed will include: single-family detached houses (old and new), row houses (old and new), and a R-2000 home. To date, we have been able to locate no specific information for characteristics of commercial buildings in Toronto. Previous research, focused on estimating the impact of reflective roofs in eleven U.S. metropolitan areas, has shown that offices (new and old) and retail stores (new and old) offer the greatest potential cooling energy savings (Konopacki et al., 1997). For this study, we intend to focus on collecting data primarily for these two building types. 
Table A.1. Housing characteristics in the Greater Toronto Area (Source: NRCAN, 2001a).

\begin{tabular}{|c|c|c|c|c|c|c|}
\hline \multirow[b]{2}{*}{ Parameter } & \multicolumn{3}{|c|}{ Single-Family Houses } & \multicolumn{3}{|c|}{ Row-Houses } \\
\hline & All & Pre-1980 & $1980+$ & All & Pre-1980 & $1980+$ \\
\hline Year Built & 1951 & 1943 & 1989 & 1935 & 1924 & 1984 \\
\hline Floor Area $\left(\mathrm{m}^{2}\right)$ & 292 & 272 & 382 & 183 & 189 & 159 \\
\hline Footprint $\left(\mathrm{m}^{2}\right)$ & 97 & 93 & 113 & 53 & 55 & 45 \\
\hline Furnace SS Eff $(\%)$ & 82 & 82 & 85 & 83 & 81 & 92 \\
\hline DHW Energy Fac & 0.60 & 0.61 & 0.58 & 0.61 & 0.59 & 0.70 \\
\hline Ceiling Ins $(\mathrm{K} . \mathrm{m} 2 / \mathrm{W}) *$ & 3.70 & 3.42 & 4.99 & 2.73 & 2.24 & 4.92 \\
\hline Fnd Wall Ins (K.m2/W) & 1.01 & 0.90 & 1.52 & 0.87 & 0.74 & 1.46 \\
\hline Main Wall Ins (K.m2/W) & 1.46 & 1.23 & 2.48 & 1.42 & 1.13 & 2.71 \\
\hline Total Occupants & 3.7 & 3.6 & 4.0 & 3.6 & 3.6 & 3.6 \\
\hline Temp Bsmt (C) & 20.1 & 20.1 & 20.2 & 20.2 & 20.1 & 20.5 \\
\hline Temp Main (C) & 21.0 & 21.0 & 21.1 & 21.0 & 20.9 & 21.2 \\
\hline Volume $\left(\mathrm{m}^{3}\right)$ & 730 & 681 & 954 & 458 & 472 & 397 \\
\hline $\mathrm{ACH} @ 50 \mathrm{~Pa}$ & 8.0 & 8.7 & 5.0 & 12.4 & 13.2 & 8.7 \\
\hline ELA @ $10 \mathrm{~Pa}(\mathrm{~cm} 2)$ & 2132 & 2218 & 1740 & 2197 & 2412 & 1249 \\
\hline \multicolumn{7}{|l|}{ Number of Stories } \\
\hline$\% 1$-story & 23.0 & 27.4 & 2.9 & 3.1 & 3.8 & 0.0 \\
\hline$\% 1 \frac{1}{2}$-stories & 2.7 & 3.1 & 0.6 & 0.5 & 0.6 & 0.0 \\
\hline$\%$ 2-stories & 59.6 & 53.0 & 89.4 & 63.5 & 63.9 & 62.0 \\
\hline$\% 2 \frac{1}{2}$-stories: & 5.4 & 6.6 & 0.0 & 5.7 & 6.7 & 1.4 \\
\hline$\% 3$-stories & 9.4 & 9.9 & 7.1 & 27.1 & 24.9 & 36.6 \\
\hline \multicolumn{7}{|l|}{ Heating Fuel } \\
\hline$\%$ Natural Gas & 88.2 & 86.0 & 98.2 & 83.9 & 92.3 & 46.5 \\
\hline$\%$ Oil & 6.4 & 7.8 & 0.0 & 2.3 & 2.9 & 0.0 \\
\hline$\%$ Electricity & 5.4 & 6.2 & 1.8 & 13.8 & 4.8 & 53.5 \\
\hline$\%$ Propane & 0.0 & 0.0 & 0.0 & 0.0 & 0.0 & 0.0 \\
\hline$\%$ Wood & 0.0 & 0.0 & 0.0 & 0.0 & 0.0 & 0.0 \\
\hline \multicolumn{7}{|l|}{ DHW Fuel } \\
\hline$\%$ Natural Gas & 83.0 & 80.8 & 92.9 & 81.8 & 90.1 & 45.1 \\
\hline$\%$ Oil & 0.3 & 0.4 & 0.0 & 0.0 & 0.0 & 0.0 \\
\hline$\%$ Electricity & 16.7 & 18.8 & 7.1 & 18.2 & 9.9 & 54.9 \\
\hline$\%$ Propane & 0.0 & 0.0 & 0.0 & 0.0 & 0.0 & 0.0 \\
\hline$\%$ Wood & 0.0 & 0.0 & 0.0 & 0.0 & 0.0 & 0.0 \\
\hline
\end{tabular}

* To convert to British units multiply by 5.68 . 

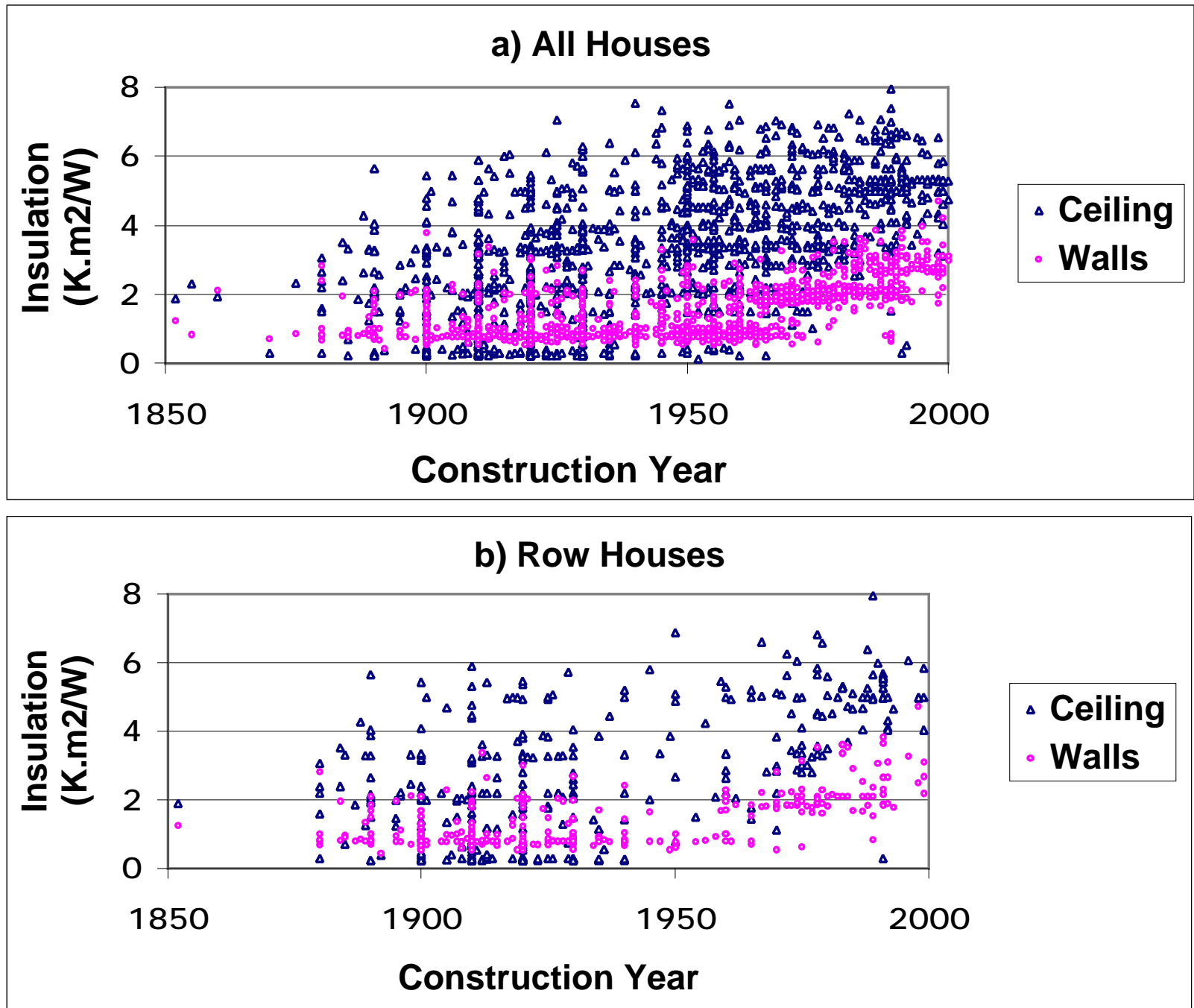

c) Single-Family Detached Houses

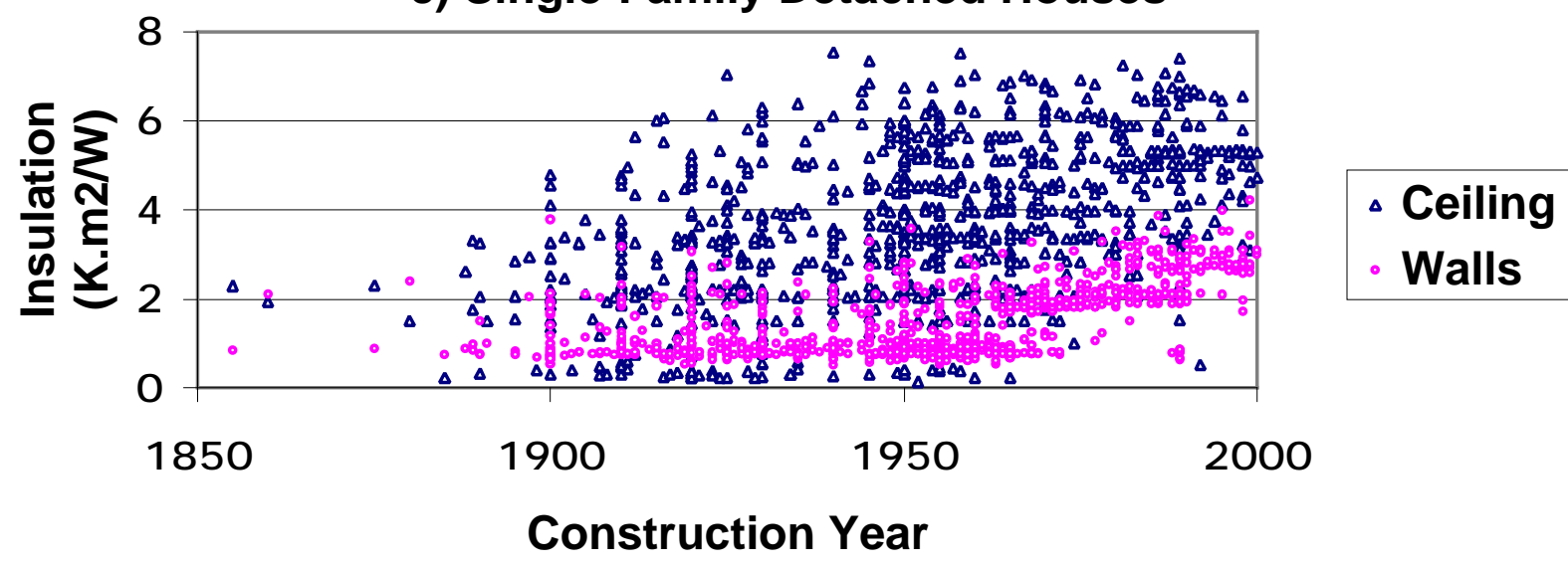

Figure A.1. Ceiling and wall insulation for a) all houses, b) row-houses, c) single-familydetached houses. 
Table A.2. Building types (partly based on data from draft report 89-78-K, Ontario Hydro Research Division).

\begin{tabular}{|c|c|c|c|c|c|c|c|c|}
\hline Type of building & $\begin{array}{l}\text { Floor } \\
\text { area }\left(\mathrm{ft}^{2}\right)\end{array}$ & Foundation type & $\begin{array}{l}\text { Exposed wall } \\
\text { area }\left(\mathrm{ft}^{2}\right)^{1}\end{array}$ & $\begin{array}{l}\text { Roof area } \\
\left(\mathrm{ft}^{2}\right)^{2}\end{array}$ & $\begin{array}{l}\text { Total window } \\
\text { area }\left(\mathrm{ft}^{2}\right)^{3}\end{array}$ & $\begin{array}{l}\text { Total door } \\
\text { area }\left(\mathrm{ft}^{2}\right)\end{array}$ & $\begin{array}{l}\text { Number } \\
\text { of stories }\end{array}$ & $\begin{array}{l}\text { Wall perimeter } \\
\text { length (ft) }\end{array}$ \\
\hline Row- houses & 1716 & Full basement & 956 & 946 & 108 & 35 & 2 & $118(26 \times 33)$ \\
\hline Detached, one-story & 1084 & Full basement & 1367 & 1200 & 100 & 35 & 1 & $134(27.8 \times 39)$ \\
\hline Detached, two-story & 2170 & Full basement & 2465 & 1200 & 215 & 35 & 2 & $134(27.8 \times 39)$ \\
\hline
\end{tabular}

1 This includes the areas of windows and exterior doors

2 This is the actual area of the gable (inclined) roof

3 Uniformly distributed on all exposed walls

Table A.3. Thermal integrity (partly based on data from draft report 89-78-K, Ontario Hydro Research Division).

\begin{tabular}{|c|c|c|c|c|c|c|c|}
\hline Type of building & $\begin{array}{l}\text { Roof ins. } \\
(\mathrm{R})\end{array}$ & $\begin{array}{l}\text { Exposed } \\
\text { ceiling ins. (R) }\end{array}$ & $\begin{array}{c}\text { Exterior } \\
\text { walls ins. (R) }\end{array}$ & $\begin{array}{l}\text { Windows } \\
(\mathrm{R})\end{array}$ & $\begin{array}{c}\text { Doors (R) } \\
\begin{array}{c}\text { Basement } \\
\text { walls (R) }\end{array}\end{array}$ & $\begin{array}{l}\text { Basement } \\
\text { floor (R) }\end{array}$ & $\begin{array}{l}\text { Infiltration/ } \\
\text { ventilation }\end{array}$ \\
\hline Existing(all-electric) & 29 & 32 & 12 & $2^{4}$ & $3.5^{5}$ & $6^{6}$ & 0.5 \\
\hline (gas-heated) & 19 & 30 & 0 & $2^{4}$ & $3.5^{5}$ & 0 \\
\hline R-2000 (electric and gas) & $40^{7}$ & $32^{7}$ & $20^{7,8}$ & $2^{7,9}$ & $4^{7}$ & 0 & $110 \mathrm{cfm}$ \\
\hline
\end{tabular}

4 Double glazing

5 Wood sash with storm

6 Average value

7 Instead of detailed envelope specification, the R-2000 code can be met by observing pre-set total annual energy targets in kWh/year (Source: House Wrap, Conference and Exhibition on Innovative Residential Building Products, Dec. 1988 EnerMark):
Windsor: 18700 Toronto: 19600
Ottawa: $20700 \quad$ North Bay: 21900
Thunder Bay: 22700
Timmins: 23500 Moosones: 24900
Trout Lake: 26300

8 R-24 for Timmins and North

9 Double glazing (and R-2.6 for Timmins and North)

10 To floor

11 or $<0.45$ ach (whichever is smaller). Additional requirements: leakage area $=1 \mathrm{in}^{2} / 100 \mathrm{ft}^{2}\left(\operatorname{existing}=3 \mathrm{in}^{2} / 100 \mathrm{ft}^{2}\right)$. 
Table A.4. Internal loads, equipment, and thermostat settings.

\section{THERMOSTAT SETTING:}

Heating thermostat setting: $21^{\circ} \mathrm{C}$ (night set back to $15.6{ }^{\circ} \mathrm{C}, 11 \mathrm{pm}$ through $7 \mathrm{am}$ ) Cooling thermostat setting: $25.5^{\circ} \mathrm{C}$

\section{INTERNAL LOAD:}

3.2 people per house (time average) lights $\left(\sim 5.4 \mathrm{~W} / \mathrm{m}^{2}\right)$

\section{HEATING AND COOLING EQUIPMENT}

Houses under $180 \mathrm{~m}^{2}$

$75,000 \mathrm{Btu} / \mathrm{h}$ gas-furnace

$36,000 \mathrm{Btu} / \mathrm{h}$ air-conditioner

Maximum, electric heaters $=12 \mathrm{~kW}$

Maximum, other equipment $=0.5 \mathrm{~kW}$

Houses over $180 \mathrm{~m}^{2}$

Two 75,000 Btu/h gas-furnaces

Two $36,000 \mathrm{Btu} / \mathrm{h}$ air-conditioners

Maximum, electric heaters $=18 \mathrm{~kW}$

Total, other equipment $=0.75 \mathrm{~kW}$

\section{EFFICIENCY:}

Existing stock:gas furnace eff.: $60 \%$

Air-conditioner c.o.p: 2.17

Electric resistance heater eff.: $100 \%$

R-2000 stock: gas furnace eff.: 78\%

Air-conditioner c.o.p: 2.7

Electric resistance heater eff.: $100 \%$

\section{HOT WATER HEATER:}

40 gallons capacity (located in basement). 